\title{
BLACK PROTEST EVENTS IN THE US 1994-2010: ISSUES, CAMPAIGNS AND TRENDS ${ }^{1}$
}

\author{
Pamela Oliver, University of Wisconsin - Madison \\ Pamela.Oliver@wisc.edu orcid.org/0000-0001-7643-1008 \\ Alex Hanna, Google \\ alex.hanna@gmail.com orcid.org/0000-0002-8957-0813 \\ Chaeyoon Lim, University of Wisconsin - Madison \\ chaeyoon.lim@wisc.edu orcid.org/0000-0003-4527-4390
}

\begin{abstract}
This paper fills a major empirical gap in providing the first systematic data about US Black movement protests between the 1994 and 2010. There is a dearth of systematic information about the Black movement and Black protests between 1995 and its reemergence in Black Lives Matter in 2012. Using a new automated system, we identified 1017 events in 1049 news wire stories relevant to Black protest between 1994 and 2010 from the Annotated English Gigaword file. These data provide insight into Black activism in the between 1994 and 2010 and identify themes that are salient for both the resurgence of the Black Lives Movement after 2012 and the rise of White supremacist movements. Over a third of all protest events are about policing, generally about police violence. Other major themes include direct struggles over White vs. Black symbolic representations and access to resources, including protests over Confederate symbols, abolition of affirmative action programs, and White supremacists. The 1995 Million Man March shows up as having a significant connection to subsequent mobilization, a relationship that is confirmed by historical accounts. A third of the protests are around a wide variety of other specific issues that will require more detailed classification. Time trends show active and rising Black mobilization in the 1990s through 2001 that was interrupted by the 9/11 terror attacks and not significantly resumed until 2006-7. Overall, most protests in this era appear to have been reacting against attacks on existing benefits rather than proactively seeking new benefits. Methodologically, we show the importance of maintaining information about both events and coverage of events and of identifying the relations between events using the concepts of campaign, master event, and subevent.

NOTE: This is a draft paper based on a preliminary analysis of data. We are continuing to refine the analysis and revise the paper. Please check with us for the latest version if you wish to cite the paper. This is a wholesale revision of a 2017 paper based on what turned out to be only a subset of the events in the newswire stories, due to an error in the selection of stories fed into the MPEDS classifier.
\end{abstract}




\section{BLACK PROTEST EVENTS IN THE US 1994-2010: ISSUES, CAMPAIGNS AND TRENDS}

\section{INTRODUCTION}

This paper fills a major empirical gap in providing the first systematic data about US Black movement protests between the mid-1990s and 2010. Most research on protests in the US since the Civil Rights Era has used the Dynamics of Collective Action dataset (Soule et al. n.d.), which ends in 1995. Our data come from a new data collection effort on Black protests 19942010 based on machine coding of stories from US news wire services. We make no claim to have the definitive data for this period, nor to providing a rigorous count of events, but offer these data as a first descriptive step toward filling an important empirical gap.

An additional contribution is to show the importance of keeping track of when and how protest events were described in news stories and how the stories portrayed the relations among events. Most protest events were either discussed in multiple news stories or discussed in stories that discussed them in the context of other protest events. Most events were parts of campaigns involving multiple coordinated events and were typically discussed as parts of a larger whole. A small number of events were mentioned repeatedly and were a disproportionate share of what the media reported about the Black movement. Although collecting event data from news stories always involves finding multiple stories about the same event and multiple events in the same story, past protocols for constructing event data have eliminated these relationships. We show that maintaining rather than discarding data on these patterns permits discovery of important relationships that are otherwise difficult to see.

\section{WHAT HAPPENED TO THE BLACK MOVEMENT?}

Writing about the "doldrums" in the US women's movement between the 1920s and the 1970s, Taylor (1989) called attention to the importance of movement survival during the doldrums between periods of intense mobilization. While the Black movement never went into the doldrums between 1980 and 2012 in the same way that the women's movement did after the 1920 s, there was a decline in its visibility and prominence as a generator of newspaper accounts of protests and movement activity. Figure 1 is calculated from the publicly-available Dynamics of Collective Action (DCA) data on protests coded from the New York Times 1960-1995 (Soule et al. n.d.). It shows the decline in protests coded by the DCA team as being about an African American civil rights issue relative to all other issues after the 1970s. ${ }^{2}$ The Amenta et al. (2009) social movement organization (SMO) dataset offers the same general conclusion in their study of news coverage of organizations 1900-1995. Figures 1 and 5 in their article (pages 643 and 647) show a rise in mentions in the New York Times for African American organizations after 1940 and then a steep decline after 1968.

In combination, the available data through 1995 from the Soule et al. DCA and Amenta et al. SMO data sets both give the appearance of something of a steady-state level of Black mobilization after the mid-1970s: the movement does not go away, but it is not a central focus of mainstream news attention. McAdam et al. (2005) compare claims-making events in Chicago in 1970, 1980, 1990, and 2000 and report that the center of activity moved from the city to the suburbs and that African American issues declined markedly as a proportion of total events, as the frequencies of events about other issues rose, although the raw numbers of African American 
claims events is relatively consistent across the decades: 13 in 1970, 2 in 1980, 10 in 1990, and 4 in 2000. Jenkins, Jacobs and Agnone (2003) examine the national-level time series of protests 1948-1997 and attribute the decline of Black mobilization both to its success in the rise of Black elected officials and the decline of grievances, and to the closing of political opportunities that had been created by divided government, northern Democratic party strength, and Cold War pressures on Republican presidents.

There is literally zero systematic quantitative data on Black protest between 1995 and studies using social media data to track protests after 2012. The only source we are aware of that promises to provide systematically-collected information about patterns of Black protest since the 1990s is Patrick Rafail's ongoing and laborious project to compile data on protest events 1996-2006 in 20 US cities using local newspapers (Martin, Rafail and McCarthy 2017, Rafail 2018). These events were located using a Boolean search with general protest terms to capture candidate articles; triaging a million candidate articles by scanning headlines, lead paragraphs, and keyword contexts; and manually coding 10,953 articles in full-text reads to identify 11,858 events. The data are not public yet, but in a personal communication, Rafail reports that he identified a total of 779 events involving African-American participants, most addressing local issues, which works out to an average of 70 events per year or 3.5 events per city/year using local sources of information.

There is also little systematic qualitative or historical work about the period between 1980 and 2010. One exception is Keeanga-Yamahtta Taylor's From \#BlacklivesMatter to Black Liberation (2016), which provides an overview of the Black movement between the Civil Rights era and the Black Lives Matter period emphasizing radical organizations and grassroots mobilizations. Beth Richie's Arrested Justice Black Women, Violence, and America's Prison Nation (2012) provides an overview of organizing by Black and other women of color around issues of violence and criminal justice, including the formation of Incite! and Critical Resistance at the end of the 1990s. Taylor (2016), Rose Brewer (2003) and Bill Fletcher and Jamala Rogers (2014) describe the founding and death of the Black Radical Congress 1998-2008. Zakiya Luna discusses the politics of SisterSong, which was founded in this era (Luna 2009, Luna 2016). Activist Jamala Rogers (2015) describes thirty years of community organizations in the St. Louis area that provided the infrastructure for the Ferguson mobilization. The first 600 hits in a broad keyword search ${ }^{3}$ of SOCINDEX turned up only a handful of qualitative studies of activism between these eras. These include interviews with activists seeking to increase Black participation in the immigrant rights movement (Zamora and Osuji 2014), Black women participating in an anti-violence movement (White 2005) and African American women who are AIDS activists (Harris 2014). A special issue of Black Scholar profiled a number of Black women activists (Neville and Hamer 2006). There are also articles about protests relevant to post-Katrina development in New Orleans (Brand 2008), Black organizations engaged in defensive development in Chicago to avoid gentrification (Boyd 2008), and interactions between White environmentalists and Black civil rights leaders in a Southern county (Hines 2015). The search also turned up an analysis of the politics and rhetoric of the 2008 State of the Black Union conference (Ralph 2009). Even for recent publications, the keyword search turned up more studies of the Civil Rights and even pre-Civil Rights eras (e.g., Baxandall 2001, Bell 2004, Berg 2005, Berger 2009, Bergin 2016, Brame and Shriver 2013, Breitzer 2011, Brown 2015, Williams 2004) and studies of the post-2012 Black Lives Matter mobilizations (e.g., 
Asoka 2015, Bell et al. 2013, Bonilla and Rosa 2015, Brooms and Perry 2016, De Choudhury et al. 2016).

To sum up, there is a huge gap in systematic quantitative information about Black protest events between 1995, when the DCA data end, and 2012, when people started using studies of social media to track \#BlackLivesMatter protest events. Systematic data on New York Times coverage of protest events (Soule et al.) and organizations (Amenta et al.) suggest a steep decline in news coverage of the Black movement that probably parallels an actual decline in the pace of insurgency. At the same time, these systematic data sources through 1995, the as-yet unpublished data being collected by Rafail, and the sparse qualitative literature all suggest that Black activism continued after the Civil Rights heyday and probably provided some support or underpinnings for the resurgence of Black mobilization in the \#BlackLivesMatter movement after 2012. Systematic studies of the form and content of Black mobilization between the two peaks of mobilization will fill an empirical void and feed into theory about movement cycles.

\section{DATA AND METHODS}

The paper analyzes data obtained from the MPEDS (Machine-learning Protest Event Data System) project (Hanna 2017). MPEDS is an automated protest event coding system that aims to provide high quality protest event data using tools from supervised machine learning and natural language processing. Machine-assisted approaches to political event data have been in use for nearly 30 years, since the inception of the Kansas Event Data System (KEDS) (Schrodt and Gerner 1994). More recently, there have been several approaches which incorporate machine learning methods into their pipelines (Croicu and Weidmann 2015, Marakov et al. 2015, Nardulli, Althaus and Hayes 2015, Wueest, Rothenhäusler and Hutter 2013). MPEDS differs from other automated event data projects because it focuses on coding for protest events rather than for a wider range of political events and because it aims to collect rich information about each event. To train MPEDS, human coders read news articles and determined whether they contain accounts of protest events and, if so, coded key features of those events. These humancoded data were passed as training materials to MPEDS to "teach" it to identify articles that contain protest events. To qualify as a codable protest event, the event must involve some form of claims-making or grievance expression and the news article also must have sufficient information about the location and date, whether it occurred in public, and whether it involved non-institutional actor. Hanna (2017) provides additional methodological details.

We used the MPEDS protocol as it existed in mid-2016 to identify protests in US wire services (Associated Press Worldstream, New York Times, Los Angeles Times/Washington Post,) for 1994-2010 in the Annotated English Gigaword database from the Linguistic Data Consortium. ${ }^{4}$ The end point is 2010 because that is the end point in Annotated English Gigaword. We used Annotated English Gigaword because the wire service stories are already digitized and stored in a single database, thus eliminating the need for article retrieval, and because we had acquired the file while developing MPEDS. Wire services are separate operations from news desks: they generate shorter stories that may be reprinted by subscribing newspapers or used as a basis for articles written by newspaper staff. Many news wire stories are written by "stringers", writers scattered around the country who are paid by the article to contribute stories. The wire service news sources are also more decentralized geographically than a local newspaper, the articles are shorter and more focused on one issue at a time than New York Times stories and are thus more easily parsed by machine coders. Although data from news

Oliver, Hanna, Lim Black Protest 1/14/19 
wire services have seldom been used in the social movement literature, they have been widely used in the political event data analysis in political science (King and Lowe 2003, O'Brien 2010, Schrodt, Simpson and Gerner 2001, Schrodt and Gerner 1994) The same wire service article or a close paraphrase of it may appear in many different newspapers. We have no measure of the extent to which there are variations in the volume of reprinting or use of wire service stories in local newspapers. ${ }^{5}$

The articles identified by MPEDS as containing protests were filtered for those which included the words black, African-American, African American, or Afro-American and then read by undergraduate coders who followed a standard protocol to identify protest events following the criteria in Hanna (2017) and additionally determined whether the protest was by African Americans. Because we were interested in casting an inclusive net to understand the full range of Black mobilization, we included events if identifiable Black organizations or activists were mentioned as participating or supporting the event, regardless of the issue, and also included events that were likely to involve significant African American presence such as union organizing campaigns among low-wage workers or community mobilizations around homelessness in cities with large African American populations, as well as events that addressed issue of racial bias or discrimination or benefits (e.g. affirmative action) without regard to the race of the participants. We keep events in the data set even if they are only mentioned in passing or as planned future events that received no subsequent coverage in our data and may not have actually happened, but flag this for follow-up assessment or removal from the analysis. All student coding was checked, corrected and hand-processed by the first author to match up events across articles. A file of events identified by coders was sorted by location and date, and the first author worked through the descriptions of events identified by coders to generate a master list of distinct events, assigning each a unique identifier and associating that identifier with the articleevent record generated by the coder interface. This process of identifying and matching up events across articles is cognitively difficult and requires a human being who can, when necessary, refer to the original text. It also requires a protocol that records enough identifying information about events that they can be distinguished or merged. Without this process, errors in identifying events are inevitable. For example, the DCA data set includes three distinct event records for a Black protest of size 400,000 in Washington, DC on October 15, 16, and 17 of 1995. One of these is the correct entry for the Million Man March, which took place on October 16. There were associated events occurring on the days before and after the big rally, but these pre- and post- events were much smaller than the march itself and should not have been given the same size value. Nothing in the DCA data set distinguishes these three entries: an uninformed user of the data would assume there had been three rallies in a row.

Events that opposed Black protesters or that were the reason for Black protest were also included in this event inventory, as it produced the most consistent way of parsing the articles. The first author also identified subevents of larger events, the aggregation of initially separate events into single references in subsequent news accounts, and the connections of events to each other in campaigns. The first author also coded other features of the events from information tagged by the undergraduate coders.

Defining Events

Although many researchers have sought to give rigorous operational definitions of "an event" to permit event to be consistently counted, these definitions have differed between researchers depending on their research goals and are impossible to execute with complete 
consistency in practice. It has long been recognized by protest event scholars that there are inevitable problems in counting distinct events. Many events last multiple days, with ebbs and flows of action and shifting personnel and tactics over time. Different researchers have made different decisions about how to distinguish events, exactly which types of events to code, and whether to use a size cutoff. Biggs (2016) argues for focusing only on the largest events rather that attempting the impossible task of identifying all events. While we agree with Biggs about the importance of size and number of participants, we show below that intensity of media coverage is not a simple function of size: some big events are virtually ignored, some small events receive extensive news coverage, and smaller events are often parts of larger campaigns that in combination add up to bigger impacts. Smaller or barely-covered events are often clues to mobilizations that are receiving little media coverage. Further, extracting size information from news articles is an error-laden process. Different reports about the same event sometimes give substantially different size estimates, and the same article sometimes reports different size estimates (e.g. official estimates vs. what the organizers said). At least half of the news stories about protests provided no size information at all, requiring the reader/coder to infer approximate size from the context and other descriptive elements which, similarly varied between articles. An event that sounded small and insignificant in one article might be described in ways that made it sound much larger in another. Reporters" use of size terms like "small" and "large" had wildly varying meanings depending on context: a "small" group might involve 5 or 500 or 5000 or even 50,000 people, and a "large" group could be 50 or 500 or 5000 or 100,000 or close to a million.

Protest events are often fluid and evolving, and the news stories written about them are often cryptic or ambiguous. Protests often involve several different forms of action by different subsets of the protesters: there may be a large rally before or after a march by some subset of protesters, and a much smaller splinter group that engages in a more radical form of actions such as a sit-in or throwing rocks at police or through windows. Protests often involve counterprotests, sometimes at the same location and time, sometimes at a different nearby location or at a different time. Protesters often organize coordinated multiple protests at different places at the same time. Protesters often organize a series of protests about the same issue in the same on different days in the same week or month. Sometimes there are multiple separately-organized and distinct protests about the same issue on the same day by different groups doing different things at different times in different places. Often when multiple forms of action and different organizations or actors are named in an article, it is difficult to tell from the news story whether they were coordinating their actions with each other or acting independently. Additionally, the reporters who write these stories do not have protest researchers in mind, and stories often describe incidents in cryptic or disjointed ways or interweave details and incidents from several different events in different places or on different days into one story, jumping back and forth between these distinct events in a manner that can be quite confusing to even the most careful and educated human reader.

For the purposes of this paper, events were identified by identifiably distinct actions, places, actors and issues that occurred within a bounded time frame. In constructing our data, we have attempted to keep track of enough information to permit events to be aggregated or disaggregated in different ways depending on the purposes of a particular analysis. When the news stories provided enough information, we broke complex events into their component parts; when a news story described a complex event in less detail, we created only one event but mentioned the diversity of action or actors in the event description. 
Unlike prior protest event researchers, we explicitly capture the hierarchical and relational structure of events. We flag events that are all part of the same campaign, i.e. ongoing events that address the same issue over time or place. In addition, we create the concept of a master event to capture the ways in which smaller specific events are parts of larger events, a concept that can be used to link a protest and counter-protest or to link the different forms of action and actors within a protest, or to link coordinated protests occurring at the same time in different places. There is always a problem about how to "count" multi-date protests. We count an occupation or hunger fast that lasts for several days as one multi-date event, but generally code a series of protests across multiple days as distinct events unless the news source is too vague to permit disaggregation. A boycott is counted as one event, even if it lasted for years and its scope was national. Threats to boycott can often be linked to specific dated events and we treat protests tied to boycotts as distinct from the boycott itself. Multi-day marches or rides are counted as one event, but separately-described daily rallies associated them are counted as distinct events from the march or ride itself. We also count coordinated protests in different places on the same day as distinct events if the places can be identified, again unless the news source is too vague to permit disaggregation. Some "events" are statements alluding to multiple events like "protests in the last month" or "events in all 50 states" or "protests in 25 cities."

All this is to say that we treat the event data not as fixed rigorous counts but as descriptive information about what was going on in the Black movement. We are attempting to structure the data so that subsequent analyses can parse or group or select events in different ways for different purposes. In addition, we give serious attention to the reality that our data are about news accounts of protests, not directly about the protests themselves. We focus attention on the extent and timing of news stories about these events.

This search identified 1049 articles that mentioned 1017 distinct events (including subevents of larger events and master events that were aggregations of prior individual events) in a total of 1993 event-article pairs in which an event is mentioned in an article. The data are structured relationally so the units of analysis can be events, articles, mentions of events in articles, event aggregates (e.g. campaigns), or mentions of campaigns in articles. Of the events, $911(88 \%)$ are by or for Blacks or their allies while $106(10 \%)$ are anti-Black or counter-protests to Black events.

\section{Comparison With DCA}

We compared the results of our event search strategy with what appeared in the Dynamics of Collection Action (DCA) data set for the two years in both, 1994-5. Our project used automated screening by MPEDS to select news stories about protests from newswire stories in Annotated Gigaword. The DCA project identified protests in full text readings of the New York Times, so differences between them reflect both the sources and the search method. Calculating overlapping and non-overlapping events is only approximate for several reasons. First DCA includes lawsuits and we usually did not, so DCA lawsuits are excluded. Second, in both datasets there is ambiguity about what was counted as a "Black" protest, and in both data sets there are "edge" events that may or may not be considered protests that were sometimes recorded, but the two projects were not necessarily consistent in this. In several cases where both sources clearly included and coded the same basic story involving a complex sequence of interconnected events over time, the coding by the two projects yielded different numbers of events from the same story; in this case the whole thing was just counted as an overlap in coverage. Finally, there are several instances in DCA that just appear to be duplicate events and 
either we don't have the text of the story for the event or we do have the story and our read is that there is only one event in the story. In these cases, we counted the DCA event only once. In short, the comparison is not exact, but it provides a useful benchmark as the DCA data are still being used for analysis by many scholars.

Of the 112 events in our data for these two years, we match 38 or $34 \%$ to DCA event records. Conversely, these 38 events are $50 \%$ of the 74 DCA events that we count as events we would have coded. Of the 148 total events located in either source, $76 \%$ are in our data and 50\% are in DCA. There do seem to be regional differences between the samples. Events in New York, New Jersey, or Connecticut are $46 \%$ of the DCA events but only $27 \%$ of our events; $42 \%$ of the overlapping events are from New York or New Jersey. ${ }^{6}$ Of all the events for the 47 states besides New York, New Jersey, or Connecticut found in either dataset, $81 \%$ are in our data and 59\% are in DCA. For events in New York, New Jersey, or Connecticut in either dataset, $61 \%$ are in our data and $71 \%$ are in DCA.

As a more conservative comparison, there are another 24 events in DCA that have forms or issues that were not targets of the MPEDS search strategy but might have been coded under the inclusive coding rules we were using that include White events with Black opponents and non-protest forms such as meetings or verbal complaints. The 38 overlapping events are $38 \%$ of this larger $100(76+24)$ set of DCA events. Using this broader criterion, of the 63 events from NY, NJ or CT identified in either source, $48 \%$ appeared in our search and $78 \%$ appeared in DCA, while of the 111 events from other states identified in either source, $74 \%$ are in our data and $46 \%$ appeared in DCA.

We conclude that our search of the newswires found somewhat more events overall and especially more events outside the New York/New Jersey/Connecticut region.

\section{RESULTS}

\section{Articles vs events}

It is important methodologically, theoretically, and substantively to recognize that there is a non-equivalence between events and mentions of events in the news. Table 1 lays out the information to demonstrate this point. The main body of the table is the 1993 distinct mentions of events in articles: a single event that was mentioned in seven articles, for example, contributes seven entries to the table; an article that mentions three events contributes three entries. The columns are for the number of events per article and the rows are the number of articles per event. An extra pair of columns tallies the 1017 events and the bottom two rows tallies the 1049 articles. Comparing the total number of mentions in a row to the total number of events, and the number of mentions in a column to the total number of articles should help to clarify the relation between events and mentions of events. For example, there were 56 events that were mentioned three times each, yielding 168 mentions. There were 129 articles that mentioned three events, yielding 387 mentions.

Of these 1993 event-article pairs, only 217 (11\%) involved one article per event and one event per article. Most (70\%) events were mentioned only once and nearly half of all articles $(49 \%)$ mentioned more than one event. Of the 713 events that were mentioned only once, only $217(30 \%)$ were the only event in that article, while the large majority (70\%) of the one-mention events were discussed in stories that involved other events. Conversely, of the 530 articles that discussed only one event, only 217 (41\%) were the unique source for that event, while a majority

Oliver, Hanna, Lim Black Protest 1/14/19 
(59\%) of the articles mentioning only one event discussed an event that was mentioned in other articles.

The three articles that mentioned more than 7 events were: a 2000 Martin Luther King Day round-up that included South Carolina flag protests, as well as mentioning a march of 100,000 people in Miami with no other information given; an article about the K-mart boycott that mentioned protests in several cities; and an article about South Carolina and Georgia flag protests and boycotts. The four articles that mentioned seven events included a summary of the Florida affirmative action protests; an article about the South Carolina Confederate flag protests; an article describing protests happening in different cities on the day of the big Jena Louisiana march; and an article describing the various activities and groups that had been inspired by the Million Man March six months later.

Figure 2 shows event coverage follows a power law: most events are mentioned only once while a few events are mentioned repeatedly. (Andrews and Caren 2010, Seguin 2016, van de Rijt et al. 2013, Walgrave and Vliegenthart 2010). Figure 3 conveys the proportion of total event mentions accounted for by the most-mentioned events. Four of the 1017 events accounted for $10 \%$ of the event mentions and 13 events (1\%) accounted for nearly $20 \%$ of the event mentions. Tables $2 \mathrm{a}$ and $2 \mathrm{~b}$ summarize the 31 events that were covered in more than six articles.

Both the flow of specific events and the flow of writing or talking about events matters. From the perspective of the physical act of protesting, each event happens only once, no matter how often it is written about, and each event is anchored in time and space and involves a given number of people. Events that get little or no news coverage when they happen may still be important pointers to people organizing and trying to get attention about a problem. But from the point of view of the audience of protest, the people to be influenced by it, the impact of an event is more likely to be related to how often they read or hear about it. Events that were physically comparable in the number of participants and what they did got vastly different volumes of news coverage in these stories.

\section{Timing of the Protests}

Figure 4 shows the distribution of events across time. A red line marks 9/11/2001 as there seems to be a clear discontinuity in the series, with protest numbers plummeting after that date. Events in New York City are highlighted because they may especially have been affected by $9 / 11$. Black protests as reported in the news wires did not really pick up again until 2006 . Prior to $9 / 11$, there may have been a protest wave building. There was a peak of events in late 1995 and early 1996 and another peak right around January 2000. Figure 5 shows that number of articles about protest per month following the same pattern. It is possible that the decline in events appearing in the news is at least in part a "news hole" effect due to the news coverage devoted to the War on Terror and the Iraq War. Relatedly, the 1990s was sometimes discussed as a "slow news" decade after the end of the Cold War. However, other sources suggest that there was a true rise in protest in the 1990s followed by its sudden decline after 9/11. The Rodney King beating and the huge Los Angeles riot in 1992 evoked a great deal of public discussion of race and police brutality. ${ }^{7}$ The Million Man March in 1995 and the publicity around the OJ Simpson trial similarly raised racial issues. Black racial consciousness was generally rising in the 1990s. Several new Black or mixed-race organizations formed at the end of the 1990s and emphasized criminal justice issues, including Incite!, Critical Resistance, and the Black Racial Congress (Brewer 2003, Fletcher and Rogers 2014, Taylor 2016). The ACLU and the NAACP were also 
building campaigns against racial profiling in policing. Both the rise in Black political activism and its sudden decline after $9 / 11$ are discussed in these sources.

\section{Event Size and Event Coverage}

The number of participants in an event is generally considered to be a big factor in its impact and newsworthiness, and the number of participants certainly should say something about the number of people who care about an issue. However, size of an event does not directly correlate with how much news coverage it gets. We have not yet completed the process of parsing the generally incomplete and inconsistent information about event size into a "size" variable. Most events involved relatively few participants ranging from handfuls to several thousands. Subsequent sections of this draft qualitatively describe the events and campaigns that receive the most news coverage. Although some of the largest events (more than 100,000) received a great deal of news coverage, many very large events did not.

The event that was both very large and very newsworthy was the 1995 Million Man March called by Louis Farrakhan and ultimately attended by a minimum of 400,000 people and probably more like 800,000. It became a huge topic of discussion among African Americans and others, partly because of its focus on men, but as it developed it became a huge mobilization of Black solidarity which had demonstrable impacts on subsequent mobilizations.

A 2010 Glenn Beck rally held at the Lincoln Memorial on the anniversary of the March on Washington had a permit for 300,000 and is in the data because of a much smaller Black counter-protest and complaints about Beck calling Obama racist; it received extensive coverage.

Other very large events (clearly involving more than 100,000 people) were mentioned only once or twice. These included: (1) The 1996 Stand for Children rally, put on by a broad coalition of liberal groups that included some Black organizations, estimated attendance 300,000. (2) A 1997 Promise Keepers rally of several hundred thousand men that had racial reconciliation as a major theme and many Black speakers, although reports said the crowd was overwhelmingly white; (3) The Million Family March of 2000, jointly sponsored by Louis Farrakhan of the NOI and Rev. Moon of the Unification Church, planning for 300,000. (4) A march of 100,000 in Miami on Martin Luther King Day in 2000, which received one sentence of mention. (5) A 2004 March for Women's Lives (pro-abortion rally that included a Black organizational sponsor) had "vast crowds" and a planned size of 300,000. (6) The very large crowds in Chicago and elsewhere the night Obama was elected president in 2008 were mentioned but the crowds themselves were not a "story."

There were also very large crowds at Black spring break festivals, including Freaknik in Atlanta in 1994, 1995 and 1996 and Dayton Black Reunion in 1999 (and other years mentioned), which were covered because of violence or disruption that occurred as spin-offs from the events.

Large crowds (more than 10,000) included: (1) the 46,000 organized by the NAACP on Martin Luther King Day in 2000 to march against the South Caroline display of the Confederate flag which received extensive coverage; (2) the 20,000 who marched in Jena, Louisiana in 2007 about the "Jena 6," plus a large but not well-counted number who attended Jena 6 events in other cities on the same day, which received extensive coverage; (3) Two of the 1999 Diallo protests in New York appear to have had more than 10,000 present, although reports vary or are unclear; these events were part of extensive coverage of an extended multi-event campaign; (4) A 2000 protest of 10,000 led by Jesse Jackson outside a Dearborn department store about store security killing a customer, two article mentions; (5) A 1994 protest in Philadelphia about 
staying the execution of Mumia Abu-Jamal attracted at least 10,000, covered as part of a broader campaign. (6) A Nation of Islam rally in Chicago in 2000, 20,000, mentioned in one article about Farrakhan; (7) A Christian Youth rally of 10,000 in 1996 in DC that included Black participants, 10,000 . There were many events described as involving "thousands" of participants. Some received more coverage than others.

Events involving fewer people that received extensive coverage included the riots in Cincinnati and Oakland around police killings, the Million Youth marches of 1998 and 1999, the events at Freddy's, the jail riots in Los Angeles, the basketball sit-in at Rutgers, the Brown students stealing the campus newspaper, the standoff between the KKK and Black militants in Jasper, and the various boycotts, whose size is hard to determine.

\section{Issues and Campaigns}

Table 3 shows the counts and percentages of the broad issue groups into which events were classified in this first round of coding. Most of the events are Black events, but we also include anti-Black events that turned up in the searches. Most of these are White supremacist or pro-Confederate or pro-police events. Figure 6 shows the proportion of events, articles, and event-mentions that addressed a given issue. (Articles that mentioned multiple events may fall in the Multiple Issue slice of the articles pie chart.) We will do more detailed coding of issues as this project unfolds, but it was obvious in the first pass of reading and coding the articles that policing and police violence were the most frequent issues that sparked Black protest, with more than a third of all news coverage of protests that involved Black people centering on policing: $30 \%$ of all events, $35 \%$ of all articles discussing events and $37 \%$ of all event-article mentions involved policing issues. The "economic" category includes a wide range of specific issues including union campaigns, complaints about employment or consumer discrimination, and concerns about poverty or homelessness or economic development or social programs that will require more detailed coding. White Supremacy includes events initiated by White supremacist groups and racially-motivated hate crimes. Confederate references events for or against Confederate symbols. Black History references celebrations of Martin Luther King Day and other events and commemorations of the Civil Rights Movement or Black history; most of these events are celebratory, but there are some remember trauma and some counter events opposing these celebrations or memorials. Group Conflict encompasses inter-group violence that did not involve White supremacists and includes verbal or physical attacks on Blacks by others, by Blacks on other groups, and inter-ethnic brawls. Solidary encompasses events whose purpose is to build Black pride or morality or solidarity; most in the data are sponsored by the Nation of Islam and are Million Man March events are spin-offs. The Other category is a collection of many different kinds of issues, including broad coalitions with other groups, voting campaigns, anti-violence and anti-crime campaigns, events for and against gay rights, educational issues and many more.

Reading all the stories as part of checking student coders and not just relying on disembodied codes made it clear that the news stories were constructing narratives about how events connected to other events and that attending to these sequences and connections is essential for understanding protest event data in context.

A majority, $61 \%$, of the events were part of a campaign involving at least two related events. Table 4 summarizes the 18 campaigns (sets of related events) that were discussed in eight or more articles. Together they accounted for $41 \%$ of all the articles in these data. Five of these 
widely-covered campaigns were about police killings (three in New York) and another two (Jena6 and Mumia) were about race and the criminal justice system, adding up to $21 \%$ of all news coverage.

Figure 7 shows the timing of protests for six of the issue categories, and Figure 8 shows the timing of article publications for these same categories.

As we consider the issues about which Black people protested, we pay attention to whether the protest campaigns appeared to be proactive or reactive. Proactive protests are initiated by movements to push for new benefits. The movement chooses the issue and chooses when and how to launch the campaign. Reactive protests are defensive responses to suddenly imposed grievances or to threats of loss.

\section{Police Violence}

While the 2014 slogans "stop killing us" and "Black Lives Matter" were new, the data show the ongoing importance of issues of policing and especially police violence in Black protest. A small number of big campaigns accounted for $66 \%$ of the news coverage of this issue: $49 \%$ of the 395 articles that mentioned policing issues were for three campaigns (Cincinnati 2001 police killing of Timothy Thomas followed by four days of rioting, New York 1999 Diallo police killing, Jena 62007 overcharging in a school fight and under-punishing hate crimes), and another three (Sean Bell police killing New York 2006, Oscar Grant police killing Oakland 2009, Mumia Abu-Jamal death penalty 1995-2001) accounted for 17\%. But there were protests about policing, usually police killings, reported in newswire articles for 56 different specific cities. Often the articles were cryptic and vague about exactly how many people had protested and when. Exploratory Internet searches revealed that some of these cryptic references referred to extensive protest campaigns that were considered major issues in the cities involved, an example of how even a slight reference in one source might point to a much bigger campaign.

The first panels of figures 7 and 8 show two peaks for events around police, one in the late 1990s that included several overlapping New York campaigns and another in late 2007 and early 2008 around the Jena protests.

We will do more detailed textual analysis of how protests against police violence were discussed in a separate article, but there seemed to be differences in the coverage of New York events versus others, partly tied to the behavior of the protesters but also to the behavior of the police and the reporters. Coverage of New York protests often mentioned the protesters and their specific actions, and the protests themselves often involved creative disruptive tactics and what appeared to be planned arrests. By contrast, coverage of events in Cincinnati and Oakland focused most heavily on the police and their tactics and the number arrested and the dollar value of property damage, giving no clear description of the peaceful protests that preceded the "riot" that became the focus, nor even of the "riots" themselves. It was difficult in both cases to decipher how many people had been involved in rioting and exactly what most of them had done. In several cases, there articles describe a sequence of events that implies that the police may have provoked the riot by aggressive tactics against peaceful protesters. There is one wellattested case in which the Cincinnati police pulled up to a group of protesters standing around peacefully after the victim's funeral, shot beanbags at them, then drove off.

Although the beanbag incident in Cincinnati was surprising and egregious, in all the cases with extensive news coverage, there are incidents of police show of force and there are many 
cases in the data of pro-police rallies following protests about police violence. The invocation of "Blue Lives Matter" in the face of "Black Lives Matter" protests 2014-2016 was merely the latest iteration of an ongoing protest dynamic.

Although most of the protests about policing were reactive, there were also proactive campaigns against racial profiling in the late 1990s and into 2001, including both the generation of statistical reports and disruptive protests.

\section{White Supremacy, White Pushback, Contests About History}

Affirmative action and related issues such as reparations accounted for 5\% of events and $4 \%$ of articles. These were generally reactive protests to proposals to dismantle affirmative action programs in California, Texas, Florida, and Louisiana. There were also protests provoked by David Horowitz who toured college campuses to oppose the idea of reparations for slavery and sought to publish an article with his ideas in college newspapers. There was a proreparations campaign at the time that was sparked by Randall Robinson's The Debt (2000) and was receiving press attention, ${ }^{8}$ but no proactive pro-Black events around reparations appeared in our data.

Overt White supremacists accounted for $9 \%$ of events and 5\% of articles involving Black protest. In this period, the White supremacist groups were very small, and the counter-protesters typically outnumbered them by a large margin. White supremacist violence took the form of hate crimes, not disruptive protest, and the police role was generally to protect the White supremacists from the counter-protesters. Their protests seemed intended to draw large numbers of police (typically a few hundred) and create a situation where counter-protesters would be the ones confronting police. In Toledo in 2005, for example, Nazis insisted on marching without a permit in a Black neighborhood. Although the police refused to issue a permit, they nevertheless showed up to protect the Nazis and escort them through the Black neighborhood. Once Black people started confronting the police, the Nazis went home, and it turned into a "Black riot" against the police. Most of these events received only one or two news mentions, but the announced standoff between a dozen KKK members and 30 Black nationalists in the small town of Jasper, Texas after a brutal and widely-publicized hate crime turned into a media circus with hundreds of police and reporters and bystanders.

The victories of the Civil Rights Movement were never final and there was substantial resistance to Blacks and other minorities in the study period. Seven percent of events and five percent of articles about Black protests concerned Confederate symbols, especially the flag. South Carolina and other Southern states re-introduced the Confederate flag into their state flag displays in the 1960s as an act of defiance against the Black Civil Rights Movement. In 1994, the NAACP and the SCLC launched proactive campaigns in South Carolina and Georgia to remove the Confederate symbol from the state flag; these efforts provoked counter-protests. The campaign heated up again in 2000, beginning with a call in late 1999 for a tourism boycott of South Carolina by the South Carolina NAACP; this boycott was mentioned in 38 wire service stories. There was a large 46,000-person anti-flag march on King Day in 2000 and other protests on other days, as well as a series of smaller pro-flag counter-protests. There were also spin-off protests and boycott threats in Georgia, including a threatened boycott of the NCAA games to be played in Atlanta, and a march and counter-march in Florida. South Carolina tried to compromise in mid-2001 by removing the flag from the Capitol itself and placing in on the ground front of the Capitol, but that resolution pleased neither side and the protests continued at 
a lower frequency for the rest of the decade. The Confederate flag was finally removed from the South Carolina Capitol grounds on July 10, 2015 (after the study period) in the wake of White supremacist Dylann Roof's massacre of nine people at Emanuel African Methodist Episcopal Church in Charleston and Black activist Bree Newsome's physical removal of the flag several weeks before its official removal.

\section{History and Solidarity}

Seven percent of events and five percent of articles concerned the memorialization of Black history, including celebrations of Martin Luther King Day, commemorations of the anniversaries of major civil rights events, and the death of Rosa Parks. The campaign to have King's birthday declared a holiday began shortly after his death. President Reagan signed the federal holiday into law in 1983 and it was first celebrated in 1986. The campaign to gain state recognition for the holiday involved tourism boycotts of some states, especially Arizona 1987-1992, and debates about the symbolism of reducing the days allocated to celebrating the birthdays of Washington and Lincoln. A flurry of King Day coverage peaked in the news wires in 2000, the first year the holiday was celebrated in all 50 states. Rosa Parks died in late October 2005, shortly before events that were already planned for the December 2005 celebration of the $50^{\text {th }}$ anniversary of the Montgomery Bus Boycott. There were many specific events in Washington DC, Montgomery, and Detroit that were part of Parks's funeral, and then many more events a few weeks later in early December memorializing both Parks and the boycott.

Five percent of events and $10 \%$ of articles discussed what we call Black solidarity events. The single largest Black protest event of the mid-1990s was the Million Man March on October 16,1995 . This mobilization occurred in a context of heightened racial consciousness. The police beating of Rodney King in 1991 and the 1992 Los Angeles riot (and a national wave of smaller riots) after the not guilty verdict for the police who beat him were huge stories that predate these data. The verdict in the widely-televised and racially-charged OJ Simpson trial (which would not be counted as a Black movement event) occurred only 13 days before the big march. There were many follow-up events to the Million Man March all around the country in which Black people organized themselves to do pro-Black activities like voter registration or violence prevention or youth development. At the same time, the coverage of some of the events classified as "Black solidarity" events emphasized conflict, often over anti-Semitic statements by leaders of the Nation of Islam and descriptions of it as a dangerous hate group. Two "Million Youth March" rallies in New York of 6,000 in 1998 and 2,000 in 1999 sponsored by a member of the Nation of Islam received extensive coverage because authorities were trying to prevent them. The 1998 event ended in a violent confrontation between police and attendees after police used strong-arm tactics including officers in riot gear and helicopters to break up what had been a peaceful event that had gone a minute over the agreed-upon curfew. The 1999 rally was peaceful when it finally occurred, amid hundreds of police patrolling it.

\section{Ethnic Conflict}

The "ethnic conflict" category needs more analysis as in this paper it groups fights or violence between ethnic groups and verbal and economic conflicts. Nearly half of the mentions of events in newswire articles in this category as currently coded were about one case, the Freddy's conflict, in which a small daily street protest against a White-owned store by supporters of Black-owned businesses was entirely ignored by the news sources for several weeks until one of the people who had been protesting entered the store, told the Black people to leave, then set a 
fire that killed eight people. This was viewed by many as an anti-Semitic hate crime and some blamed Black activists, including Al Sharpton who had been supporting the protests. There was zero coverage of the protesters until after the arson murder, but as coverage developed the Freddy's event was tied discursively to many other stories about Harlem and Brooklyn protests and boycotts about racial-economic conflicts. The second largest group of stories coded "ethnic conflict" are a series of fights between Blacks and Hispanics in the Los Angeles jails that all occurred within a few weeks of each other in 2006; several other prison or jail riots are also included in this category. There category also includes several articles about fights between Blacks and Hispanic high school students around the big immigration protests in Los Angeles.

\section{Other Issues}

Especially in the 2000s, many events with identifiable Black participants involved coalitions or bridge-building. Black leaders and organizations were often named as participants in support of union organizing drives or strikes or in broad coalitions around social issues such as welfare or abortion (pro- and anti-) or gay rights (pro- and anti-). In some of these instances, the racial dimension was named and overt, as when firms were said to be practicing racial discrimination or anti-homeless actions were said to be racist. In other instances, the article made no overt mention of race but named Black organizations or leaders who were participating. In still other instances, we assumed that many of the participants were Black from the nature and location of the event, e.g. low-wage workers or poor residents in a majority-Black city. Some of these campaigns were proactive, many others were reactive. None of these became one of the big stories that received extensive news coverage. We need to do more detailed analysis of these diverse events.

There were huge immigrant rallies in 2006 in response to repressive anti-immigrant legislation proposed that year. We did not select or code these large rallies as they were Latinofocused. However, there are many smaller events in the data about Black protest or mobilizations that involve immigration, some in which Blacks advocate against immigrants, some in which there are attempts to build coalitions between Black Americans and Latino immigrants, and some that call attention to the needs of Black immigrants. The Black Alliance for Just Immigration was founded in 2006 in the context of this mobilization and still exists with the specific agendas of advocating for racial equality and the treatment of immigrants and of bringing Black immigrant communities into dialog and alliance with longstanding Black American communities. Additionally, many of the Black protests in the data are by Haitians, especially in New York, where most of victims of police violence at the center of major protests were Haitian, and in Miami, where Haitians protested their unequal treatment compared to Cubans.

\section{DISCUSSION}

We provide the first available systematic account of the Black movement for a 16-year period and even in this preliminary analysis reveal patterns that have not previously been recognized. The protest event data we have collected make it clear that there was significant Black activism between 1994 and 2010. The data and qualitative historical sources coincide in suggesting that Black mobilization was generally rising in the 1990s through 2001 and that this wave of protest and mobilization was interrupted by $9 / 11$, resuming in the latter half of the 2000s.

We need to pay particular attention to a movement's position in the majority-minority dynamics of a racially- and ethnically-hierarchical nation (Oliver 2017). Minority movements,

Oliver, Hanna, Lim Black Protest 1/14/19 
by their sheer minority-ness, are usually not able to take power and impose their will on others. Minority movements must thread their way through majority politics which all too often takes an anti-minority turn. They are underrepresented in "mainstream" (i.e. majority-dominated) news media and, when their movements are covered, the stories often reflect the majority standpoint or gaze, rather than the self-perception of the minority group. They require allies. Their mobilization may trigger threat responses from dominant majorities who have greater power and resources. Minorities thus are vulnerable to losing the victories they have gained through majority counter-mobilization. Politicians seeking electoral victories frequently stoke antiminority sentiments as a way of gaining votes from the majority.

These majority-minority dynamics play out in these data on Black protests. Our preliminary analysis suggests that much of this struggle was reactive and defensive rather than proactive, including especially responses to police violence, unsuccessful attempts to resist the rollbacks of affirmative action programs, and reactions to White supremacist rallies. The impression from reading the news stories about other issues is that many of them were also reactive responses to specific incidents of discrimination in employment or against customers, although these campaigns can also be understood as proactive attempts to make people stop discriminating. Also apparently reactive were a series of protests of the failure to allow the return of lower income Black residents to New Orleans after hurricane Katrina and the redevelopment of New Orleans as a whiter and wealthier city, and protests against punitive measures against homeless people.

There is evidence of attempts to move to a proactive stance in the attacks on Confederate symbols through 2001, which got extensive coverage, and in the mobilizations around disparate policing in the late 1990s, which received less attention at least in the form of news coverage of protests, and around disparate policing of youth and hate crimes, which got a great deal of attention in 2007. Careful coding may identify a proactive element in some of the campaigns around diverse issues that received less extensive coverage, as well.

The largest instance of proactive mobilization was the Million Man March which, although it did not articulate any demands on government or other targets, had the agenda of calling Black men into taking responsibility for their families and communities, and appears to have had the effect of inspiring a great deal of Black mobilization in the late 1990s. At the same time, news coverage of Louis Farrakhan and the Nation of Islam often emphasizes their antiSemitism and sometimes even treats them as a violent hate group.

There are also many instances and clues in the data of Black organizations forming alliances or coalitions with other racial groups, especially in union campaigns and urban campaigns in defense of low income people, but also in participation in broad coalitions against war, for expansion of social welfare programs, or for or against abortion or gay rights.

Methodologically, we show the importance of attending simultaneously to the news media as sources of information about protest and to the news media as actors in the protest system that contribute to outcomes. We show that it is possible to collect and construct data files in a way that makes it possible to work back and forth between alternate representations of the data as sets of events or sets of articles about events. We show the importance of recognizing the relations among events and the ways in which most events are connected to other events. We demonstrate that it is possible to define the concepts of campaign, master event, and subevent to capture the hierarchical and relational nature of events and, in so doing, provide a rich and 
flexible way of conveying information from protest event data about what activists are doing. At a practical level, this means keeping much more textual information from the source article in a data accessible with an event identifier, something that is easy to do with modern computer capacities. Article identifiers also allow the possibility of retrieving the original sources to permit a textual analysis of how events were described, and how "stories" get constructed. Several of the most frequently-repeated "stories" in these data, such as the Freddy's protesters and the sequence of events in the Jena 6 case, were never described contemporaneously, only after the fact, but nevertheless became treated in subsequent news stories as events that had triggered other events. Or, as another example, a close reading of the accounts of "riots" even in mainstream media writing from a police-identified standpoint sometimes reveal clear cases of police provocation or highly repressive policing.

For more recent protests, there is a growing body of scholarship that examines social media (e.g., Bonilla and Rosa 2015, Freelon, McIlwain and Clark 2016, Gill 2016, Hanna 2016) as a source of data about protest. These studies show the interplay of social media and social movements and also how each specific medium is different in how it is used by and interacts with social movements and other organizations. However, social media platforms are changing constantly, cannot provide any data for the 1990s or early 2000s, and provide only inconsistent and evolving data traces after the mid-2000s. If we want to fill in the empirical gap about movements of the recent past, we need to collect data from archives of news sources. A judicious use of new technologies will make it possible to process more sources and expand our empirical base of information. 
TABLES 
Table 1. Distribution of events per article and articles per event for total article-event mentions in news wire stories.

\begin{tabular}{|c|c|c|c|c|c|c|c|c|c|c|c|c|c|c|c|c|}
\hline \multirow[b]{2}{*}{$\begin{array}{l}\text { Articles per } \\
\text { event }\end{array}$} & \multicolumn{10}{|c|}{ Number events per article } & \multicolumn{2}{|c|}{ Mentions } & \multicolumn{2}{|c|}{ Events } & \multicolumn{2}{|c|}{ Cumulative Proportion } \\
\hline & 1 & 2 & 3 & 4 & 5 & 6 & 7 & 8 & 9 & 12 & $\#$ & prop & $\#$ & prop & Mentions & Events \\
\hline 1 & 217 & 185 & 107 & 83 & 56 & 26 & 14 & 8 & 9 & 8 & 713 & 0.36 & 713 & 0.70 & 1.00 & 1.00 \\
\hline 2 & 87 & 99 & 60 & 40 & 21 & 7 & 2 & 0 & 0 & 0 & 316 & 0.16 & 158 & 0.16 & 0.64 & 0.30 \\
\hline 3 & 37 & 34 & 28 & 40 & 16 & 10 & 3 & 0 & 0 & 0 & 168 & 0.08 & 56 & 0.06 & 0.48 & 0.14 \\
\hline 4 & 40 & 42 & 31 & 17 & 8 & 0 & 2 & 0 & 0 & 0 & 140 & 0.07 & 35 & 0.03 & 0.40 & 0.09 \\
\hline 5 & 14 & 17 & 9 & 9 & 3 & 2 & 1 & 0 & 0 & 0 & 55 & 0.03 & 11 & 0.01 & 0.33 & 0.05 \\
\hline 6 & 19 & 26 & 20 & 8 & 4 & 0 & 1 & 0 & 0 & 0 & 78 & 0.04 & 13 & 0.01 & 0.30 & 0.04 \\
\hline 7 & 2 & 18 & 6 & 10 & 4 & 0 & 1 & 0 & 0 & 1 & 42 & 0.02 & 6 & 0.01 & 0.26 & 0.03 \\
\hline 8 & 5 & 10 & 13 & 9 & 5 & 6 & 0 & 0 & 0 & 0 & 48 & 0.02 & 6 & 0.01 & 0.24 & 0.02 \\
\hline 9 & 6 & 5 & 5 & 2 & 0 & 0 & 0 & 0 & 0 & 0 & 18 & 0.01 & 2 & 0.00 & 0.22 & 0.02 \\
\hline 10 & 2 & 7 & 17 & 9 & 2 & 2 & 0 & 0 & 0 & 1 & 40 & 0.02 & 4 & 0.00 & 0.21 & 0.02 \\
\hline 13 & 2 & 5 & 6 & 0 & 0 & 0 & 0 & 0 & 0 & 0 & 13 & 0.01 & 1 & 0.00 & 0.19 & 0.01 \\
\hline 15 & 1 & 6 & 15 & 7 & 1 & 0 & 0 & 0 & 0 & 0 & 30 & 0.02 & 2 & 0.00 & 0.18 & 0.01 \\
\hline 16 & 8 & 8 & 4 & 6 & 4 & 0 & 1 & 0 & 0 & 1 & 32 & 0.02 & 2 & 0.00 & 0.17 & 0.01 \\
\hline 23 & 6 & 7 & 6 & 3 & 1 & 0 & 0 & 0 & 0 & 0 & 23 & 0.01 & 1 & 0.00 & 0.15 & 0.01 \\
\hline 24 & 1 & 15 & 6 & 1 & 1 & 0 & 0 & 0 & 0 & 0 & 24 & 0.01 & 1 & 0.00 & 0.14 & 0.01 \\
\hline 29 & 17 & 8 & 3 & 1 & 0 & 0 & 0 & 0 & 0 & 0 & 29 & 0.01 & 1 & 0.00 & 0.13 & 0.01 \\
\hline 30 & 5 & 15 & 7 & 1 & 2 & 0 & 0 & 0 & 0 & 0 & 30 & 0.02 & 1 & 0.00 & 0.11 & 0.00 \\
\hline 38 & 4 & 8 & 7 & 13 & 4 & 0 & 1 & 0 & 0 & 1 & 38 & 0.02 & 1 & 0.00 & 0.10 & 0.00 \\
\hline 47 & 13 & 15 & 11 & 5 & 1 & 1 & 1 & 0 & 0 & 0 & 47 & 0.02 & 1 & 0.00 & 0.08 & 0.00 \\
\hline 50 & 35 & 9 & 3 & 1 & 1 & 0 & 1 & 0 & 0 & 0 & 50 & 0.03 & 1 & 0.00 & 0.05 & 0.00 \\
\hline 59 & 9 & 19 & 23 & 7 & 1 & 0 & 0 & 0 & 0 & 0 & 59 & 0.03 & 1 & 0.00 & 0.03 & 0.00 \\
\hline Total & 530 & 558 & 387 & 272 & 135 & 54 & 28 & 8 & 9 & 12 & 1,993 & 1.00 & 1017 & 1.00 & & \\
\hline \# Articles & 530 & 279 & 129 & 68 & 27 & 9 & 4 & 1 & 1 & 1 & 1049 & & & & & \\
\hline $\mathrm{P}$ of articles & 0.51 & 0.27 & 0.12 & 0.06 & 0.03 & 0.01 & 0.00 & 0.00 & 0.00 & $\begin{array}{r}0.0 \\
0 \\
\end{array}$ & & & & & & \\
\hline
\end{tabular}


Table 2a. Events which were covered by more than 9 articles

\begin{tabular}{|c|c|c|}
\hline Event Name & Description & $\begin{array}{l}\text { Number } \\
\text { Articles }\end{array}$ \\
\hline Cincy010409_4daysriots & $\begin{array}{l}\text { General reference to the riots in Cincinnati } 2001 \text { after a } \\
\text { police killing }\end{array}$ & 59 \\
\hline MillionManMarch95 & The Million Man March, at least 400,000 people attended & 50 \\
\hline Jena bigrally 070920 & $\begin{array}{l}\text { A rally of over } 20,000 \text { people from all around the country in } \\
\text { Jena, Louisiana around over-charging Black youths for a } \\
\text { fight and under-punishing a noose hung on a tree }\end{array}$ & 47 \\
\hline SCBoycott00 & $\begin{array}{l}\text { NAACP tourism boycott of South Carolina about the } \\
\text { Confederate Flag }\end{array}$ & 38 \\
\hline FreddysPickets95 & $\begin{array}{l}\text { Pickets in front of Freddy's clothing store about conflicts } \\
\text { between Black-owned and other-owned businesses }\end{array}$ & 30 \\
\hline MillionYouth98 & $\begin{array}{l}\text { A rally of about } 6000 \text { Black youth in Harlem sponsored by } \\
\text { NOI. The city tried to prevent it and then the police attacked } \\
\text { a previously-peaceful rally in riot gear and with helicopters } \\
\text { one minute after the rally was supposed to end. }\end{array}$ & 29 \\
\hline FreddysArson95 & $\begin{array}{l}\text { A man who had been picketing at Freddy's went into the } \\
\text { store, told the Black people to leave, then set a fire that } \\
\text { killed } 8 \text { people and burned the store. }\end{array}$ & 24 \\
\hline Diallo_9903daily & $\begin{array}{l}\text { A month of daily ritualized protests at which several } \\
\text { thousand people total were arrested for blocking the doors to } \\
\text { the police station over the refusal to charge the police who } \\
\text { killed Amadou Diallo }\end{array}$ & 23 \\
\hline MillionYouth99 & $\begin{array}{l}\text { A peaceful rally of about } 2000 \text { youths sponsored by NOI } \\
\text { received extensive news coverage because the city again } \\
\text { tried to prevent it. }\end{array}$ & 16 \\
\hline SCFlag000117 & $\begin{array}{l}\text { A march of } 46,000 \text { people called by the NAACP to protest } \\
\text { South Carolina's display of the Confederate flag. }\end{array}$ & 16 \\
\hline Cincy01_lawsuitfiled & $\begin{array}{l}\text { A lawsuit about racial bias in Cincinnati policing that was } \\
\text { filed shortly before the killing that provoked the riot and } \\
\text { was litigated and settled in the riot aftermath. }\end{array}$ & 15 \\
\hline Jena_recap & $\begin{array}{l}\text { A code for a recap of the past events in Jena that led to the } \\
\text { protest. }\end{array}$ & 15 \\
\hline OGrant_100708riot & $\begin{array}{l}\text { Disorderly confrontation with the Oakland police after a } \\
\text { transit police officer killed Oscar Grant in } 2009 .\end{array}$ & 13 \\
\hline Cincy010414_funeral & Funeral of victim of police killing in Cincinnati & 10 \\
\hline OGrant_0901 & Oscar Grant protest in Oakland & 10 \\
\hline SCFlag000107_proflag & March of 6000 in favor of Confederate flag in SC & 10 \\
\hline jailriot_LA05 & $\begin{array}{l}\text { General reference to there having been several riots in Los } \\
\text { Angeles jails that month }\end{array}$ & 10 \\
\hline
\end{tabular}


Table 2b. Events which were covered by 7-9 articles

\begin{tabular}{|l|l|l|}
\hline Event Name & Description & $\begin{array}{l}\text { Number } \\
\text { Articles }\end{array}$ \\
\hline Cincy010414_march & $\begin{array}{l}\text { A protest march of 2000 people about the Cincinnati } \\
\text { police killing of Timothy Thomas }\end{array}$ & 9 \\
\hline Rutgers_Sitin & $\begin{array}{l}\text { In 1995 Rutgers students sat on the basketball court } \\
\text { and disrupted the game in protest of the Rutger's } \\
\text { president's racially biased remarks }\end{array}$ & 9 \\
\hline Brown_newspapers01 & $\begin{array}{l}\text { Brown students stole the press run of the campus } \\
\text { newspaper that printed Horowitz's anti-reparations } \\
\text { article in 2001 }\end{array}$ & 8 \\
\hline Jasper980627_KKK & $\begin{array}{l}\text { A handful of KKK members were met by 30 Black } \\
\text { militants and hundreds of reporters, police and } \\
\text { bystanders in a small Texas town where there had } \\
\text { been a hate crime in 1998 }\end{array}$ & 8 \\
\hline Jasper980627_NBP & $\begin{array}{l}\text { A handful of KKK members were met by 30 Black } \\
\text { militants and hundreds of reporters, police and } \\
\text { bystanders in a small Texas town where there had } \\
\text { been a hate crime in 1998 }\end{array}$ & 8 \\
\hline Jena_noose & $\begin{array}{l}\text { Somebody hung a noose on a tree at the Jena high } \\
\text { school; not covered at the time but often referred to in } \\
\text { stories about the Jena protests }\end{array}$ & 8 \\
\hline SeanBell080507 & $\begin{array}{l}\text { A protest about the killing of Sean Bell in 2008 by } \\
\text { New York Police }\end{array}$ & 8 \\
\hline jailriot_LA05_20060204 & A riot in a Los Angeles jail in 2005 & 8 \\
\hline & $\begin{array}{l}\text { Glenn Beck held an anti-Obama rally of hundreds of } \\
\text { thousands at the Lincoln Memorial on the } \\
\text { anniversary of the March on Washington in 2010. } \\
\text { There was a smaller Black counter-protest }\end{array}$ & 7 \\
\hline Geckrally100828 & A 2001 tourism boycott of Cincinnati about policing & 7 \\
\hline Cincy010416_boycott & $\begin{array}{l}\text { A protest by 200 people in Cincinnati the day after } \\
\text { the police killing of Timothy Thomas }\end{array}$ & 7 \\
\hline Cincy010507_protests & $\begin{array}{l}\text { Reference to daily protests in the police killing of } \\
\text { Amadou Diallo in New York in 1999 }\end{array}$ & 7 \\
\hline Diallo_9902daily & $\begin{array}{l}\text { Threatened boycott of Georgia for the Confederate } \\
\text { flag's incorporation into the state flag }\end{array}$ & 7 \\
\hline SCFlag000402 & $\begin{array}{l}\text { A protest by more than 600 people against the } \\
\text { Confederate flag in SC }\end{array}$ & 7 \\
\hline & & 8 \\
\hline
\end{tabular}


Table 3 Broad issue group for events

\begin{tabular}{|l|r|r|r|r|r|r|}
\hline & \multicolumn{3}{|c|}{ Number Events } & \multicolumn{3}{|c|}{ Percentage of Events } \\
\hline & Black* & Anti** & Total & Black* & Anti** & Total \\
\hline Policing Issues & 287 & 22 & 309 & 32 & 21 & 30 \\
\hline $\begin{array}{l}\text { Affirmative Action, Reparations \& } \\
\text { Related }\end{array}$ & 47 & 3 & 50 & 5 & 3 & 5 \\
\hline Black History Commemoration & 70 & 1 & 71 & 8 & 1 & 7 \\
\hline Confederate Symbols & 45 & 27 & 72 & 5 & 25 & 7 \\
\hline $\begin{array}{l}\text { White Supremacy (groups and racial } \\
\text { hate crimes) }\end{array}$ & 56 & 35 & 91 & 5 & 33 & 9 \\
\hline Group Conflict (Verbal or violent) & 50 & 3 & 53 & 5 & 3 & 5 \\
\hline Economic Misc. & 98 & & 98 & 11 & 0 & 10 \\
\hline Black Solidarity Events & 46 & 1 & 47 & 5 & 1 & 5 \\
\hline Other & 212 & 14 & 226 & 23 & 13 & 22 \\
\hline Total & 911 & 106 & 1,017 & 100 & 100 & 100 \\
\hline
\end{tabular}

* Events where the protagonists were Black or included identifiably Black actors. Events and counter-events can both be coded as pro-Black if the actors on both sides are or include Black people, e.g. pro- and anti-gay events by Black people. In this preliminary analysis, events that appeared to involve Black people are included even if the issue was not racial, as in union campaigns for workers who are disproportionately racial minorities or urban campaigns around economic issues.

Events where the actors were expressing opposition to issues supported by Black groups. These typically enter the data because there were Black counter-protests to them or they were counter-protests to Black protests. 
Table 4. Campaigns that received the most news coverage. Unit of analysis is 1271 campaignarticle pairs (2 page table)

\begin{tabular}{|c|c|c|c|c|}
\hline Campaign & $\begin{array}{l}\# \\
\text { articles }\end{array}$ & $\%$ & $\begin{array}{l}\text { Cum } \\
\%\end{array}$ & Description \\
\hline Cincy01 & 70 & 0.06 & 0.06 & $\begin{array}{l}2001 \text { Police killing of Timothy Thomas in Cincinnati, } 3-4 \\
\text { days of rioting, other protests. News articles focus on policing } \\
\text { and often describe police blocking or attacking peaceful } \\
\text { protests and are unclear about how many people were rioting. } \\
\text { There were a few hundred arrests. Largest march described as } \\
1000 \text { people }\end{array}$ \\
\hline Diallo & 69 & 0.05 & 0.11 & $\begin{array}{l}1999 \text { Police killing of Amadou Diallo in New York, months } \\
\text { of protest in several waves into } 2000 \text { and after that included a } \\
\text { month of daily ritualized blockades and arrests of celebrities } \\
\text { at the police station. Most events relatively small, one rally } \\
\text { may have had more than } 10,000 \text { and a couple had } 1000 \text { to } \\
\text { perhaps } 5000 \text {. }\end{array}$ \\
\hline Jena6 & 55 & 0.04 & 0.15 & $\begin{array}{l}2007 \text { protest organized on-line about over-charging } 6 \text { small- } \\
\text { town Jena LA high school students for a fight that followed a } \\
\text { noose-hanging incident. Over } 20,000 \text { people came to Jena and } \\
\text { there were coordinated protests in many other cities plus } \\
\text { follow-up rallies about the linked issues of punishing hate } \\
\text { crimes and unequal justice. }\end{array}$ \\
\hline MillionMan95 & 50 & 0.04 & 0.19 & $\begin{array}{l}1995 \text { One event. At least } 400,000 \text {, probably closer to } 800,000 \\
\text { gathered in DC at the call of Louis Farrakhan of the NOI for } \\
\text { Black men to repent and serve their families and } \\
\text { communities. Became a huge discussion topic among Black } \\
\text { people. There was much coverage at the time and many } \\
\text { references to it in follow up events. }\end{array}$ \\
\hline SCFlag00 & 42 & 0.03 & 0.23 & $\begin{array}{l}2000-1 \text { A series of protests tied to the NAACP attempts to get } \\
\text { the Confederate flag removed from the South Carolina state } \\
\text { house. One big anti-flag rally, } 46,000 \text { people on MLK Day in } \\
2000 \text { and several thousand pro-flag protesters the week before } \\
\text { plus a multi-year tourism boycott. Other events varied in size } \\
\text { from small to several thousand including counter-protests. }\end{array}$ \\
\hline MillionYouth & 40 & 0.03 & 0.26 & $\begin{array}{l}\text { 1998, 1999, } 2000 \text { The Million Youth marches in New York } \\
\text { sponsored by Kahlil Muhammad of the NOI; the city tried to } \\
\text { prevent the } 1998 \text { and } 1999 \text { marches and used excessive police } \\
\text { force to break up the } 1998 \text { event. There were } 6000 \text { attending } \\
\text { in } 1998,2000 \text { in } 1999 \text { and } 300 \text { in } 2000 .\end{array}$ \\
\hline 125thStreet & 36 & 0.03 & 0.28 & $\begin{array}{l}1995 \text { A man who had been part of a small group of Black } \\
\text { pickets outside Freddy's clothing store set the store on fire } \\
\text { and killed } 8 \text { people. After the arson/murder, there was } \\
\text { extensive coverage that tied the violence to the Freddy's } \\
\text { pickets, to other protests about } 125 \text { th Street vendors, broader } \\
\text { conflicts about Black vs. other owned businesses, and anti- } \\
\text { Semitic statements by Black protesters. }\end{array}$ \\
\hline
\end{tabular}




\begin{tabular}{|c|c|c|c|c|}
\hline Campaign & $\begin{array}{l}\# \\
\text { articles }\end{array}$ & $\%$ & $\begin{array}{l}\text { Cum } \\
\%\end{array}$ & Description \\
\hline SeanBell & 24 & 0.02 & 0.30 & $\begin{array}{l}2006 \text { Police killing of Sean Bell in New York and a series of } \\
\text { protests into } 2008 \text {. No very large protests but many smaller } \\
\text { creative disruptive protests, including six coordinated } \\
\text { simultaneous traffic-blocking events at bridges and tunnels. }\end{array}$ \\
\hline OGrant & 22 & 0.02 & 0.32 & $\begin{array}{l}2009 \text { Police killing of Oscar Grant in Oakland CA led to } \\
\text { disruptive protests and rioting in several waves. News articles } \\
\text { describe coercive policing in response to any disorder. } \\
\text { Hundreds arrested. Few size estimates, largest march seems } \\
\text { to be perhaps } 1000 \text { people. }\end{array}$ \\
\hline Mumia & 20 & 0.02 & 0.34 & $\begin{array}{l}\text { 1995-2001 A series of events seeking to block the execution } \\
\text { of Mumia Abu-Jamal for murder of a police officer. 10,000 in } \\
\text { the largest event, thousands in several others. Mixed-race } \\
\text { protesters. Often involves coordinated protests in multiple } \\
\text { cities on the same day. }\end{array}$ \\
\hline Vote 2000 & 19 & 0.01 & 0.35 & $\begin{array}{l}2000 \text { Protests around vote counting in Florida in the } \\
\text { presidential election and subsequent protests about the } \\
\text { outcome. Black groups part of larger coalitions. Tied to a } \\
\text { major political story and Constitutional crisis. Rally sizes } \\
\text { varied. }\end{array}$ \\
\hline Rutgers95 & 12 & 0.01 & 0.36 & $\begin{array}{l}1995 \text { Protests about the Rutger's president seeming to say the } \\
\text { Blacks were genetically inferior. Protests of a few hundred, } \\
\text { one disrupted a basketball game. }\end{array}$ \\
\hline jailriot_LA05 & 12 & 0.01 & 0.37 & $\begin{array}{l}2005 \text { A series of fights between Black and Hispanic inmates } \\
\text { in the jails of Los Angeles. }\end{array}$ \\
\hline Dorismond & 11 & 0.01 & 0.38 & $\begin{array}{l}2000 \text { Patrick Dorismond killed by New York police, series of } \\
\text { protests, largest was about } 3000\end{array}$ \\
\hline Decater99 & 10 & 0.01 & 0.39 & $\begin{array}{l}1999 \text { Jesse Jackson protests in Decatur IL about youths } \\
\text { expelled from school after a fight at a football game. Protest } \\
\text { sizes unclear but one article mentions "busloads." }\end{array}$ \\
\hline UCAffAct & 10 & 0.01 & 0.39 & $\begin{array}{l}1995-7 \text { Protests in California around abolishing affirmative } \\
\text { action in the UC system. Largest rally has thousands. }\end{array}$ \\
\hline CocaCola & 9 & 0.01 & 0.40 & $\begin{array}{l}2000 \text { One } 500 \text {-person rally and a five-day bus ride of } 45 \\
\text { people between Greensboro NC and Wilmington DE with } \\
\text { daily rallies (probably small) along the way to protest racial } \\
\text { discrimination in employment by Coca Cola. }\end{array}$ \\
\hline Jasper & 9 & 0.01 & 0.41 & $\begin{array}{l}1998 \text { After a widely publicized hate crime that is not in our } \\
\text { data, the KKK and the New Black Panthers scheduled dueling } \\
\text { rallies in the small town of Jasper TX. About a dozen KKK } \\
\text { and } 30 \text { Black militants showed up along with several hundred } \\
\text { each of media reporters, police, and bystanders. News } \\
\text { coverage built up to the event, and then stressed its } \\
\text { anticlimactic media circus character. }\end{array}$ \\
\hline
\end{tabular}




\section{FIGURES}

Figure 1. African American issues vs. other issues in Soule et al Dynamics of Contention protest data from the New York Times 19601995

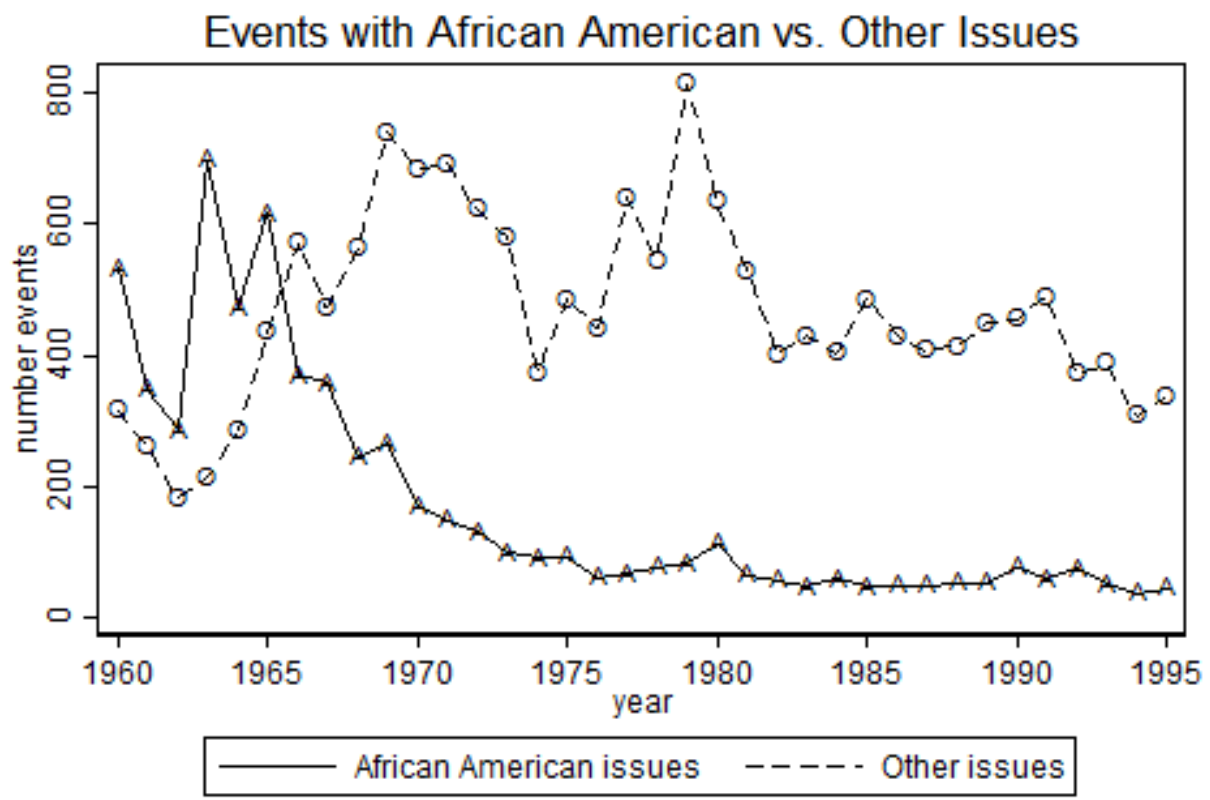

Source is Soule et al Dynamics of Contention Data Coded from New York Times 
Figure 2. Number of events by articles per event.

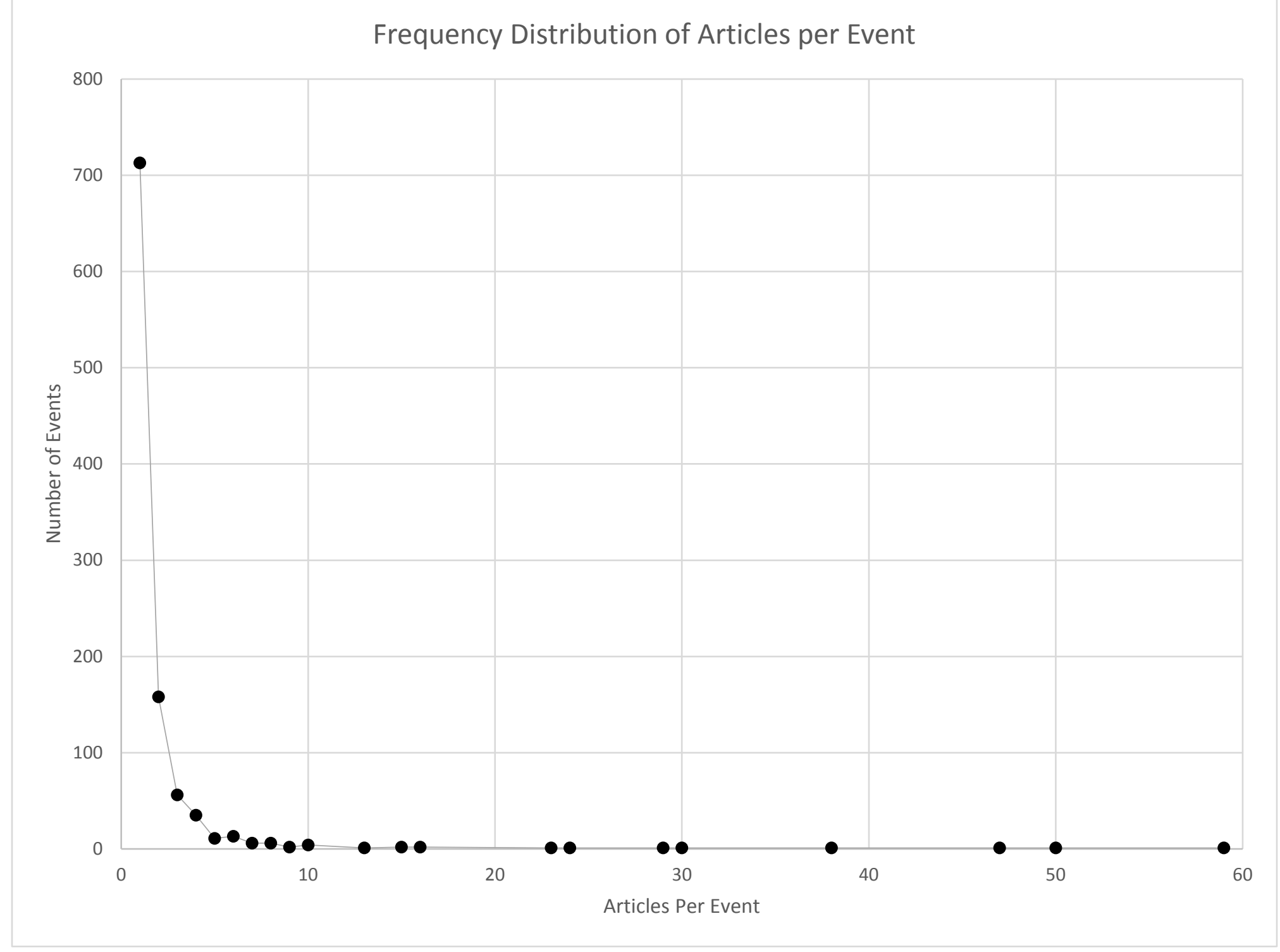


Figure 3. Cumulative proportion of coverage

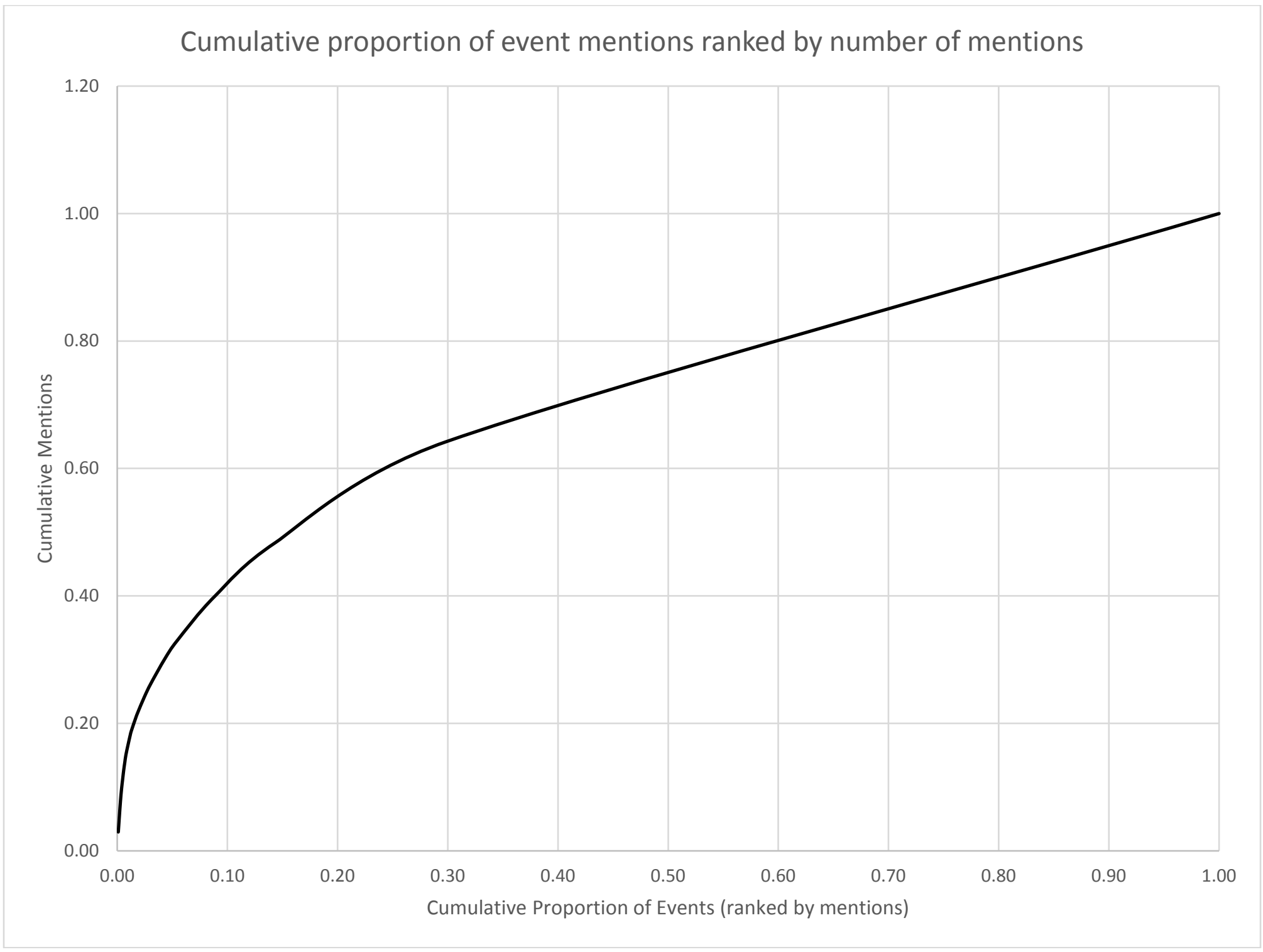


Figure 4 Timing of Events

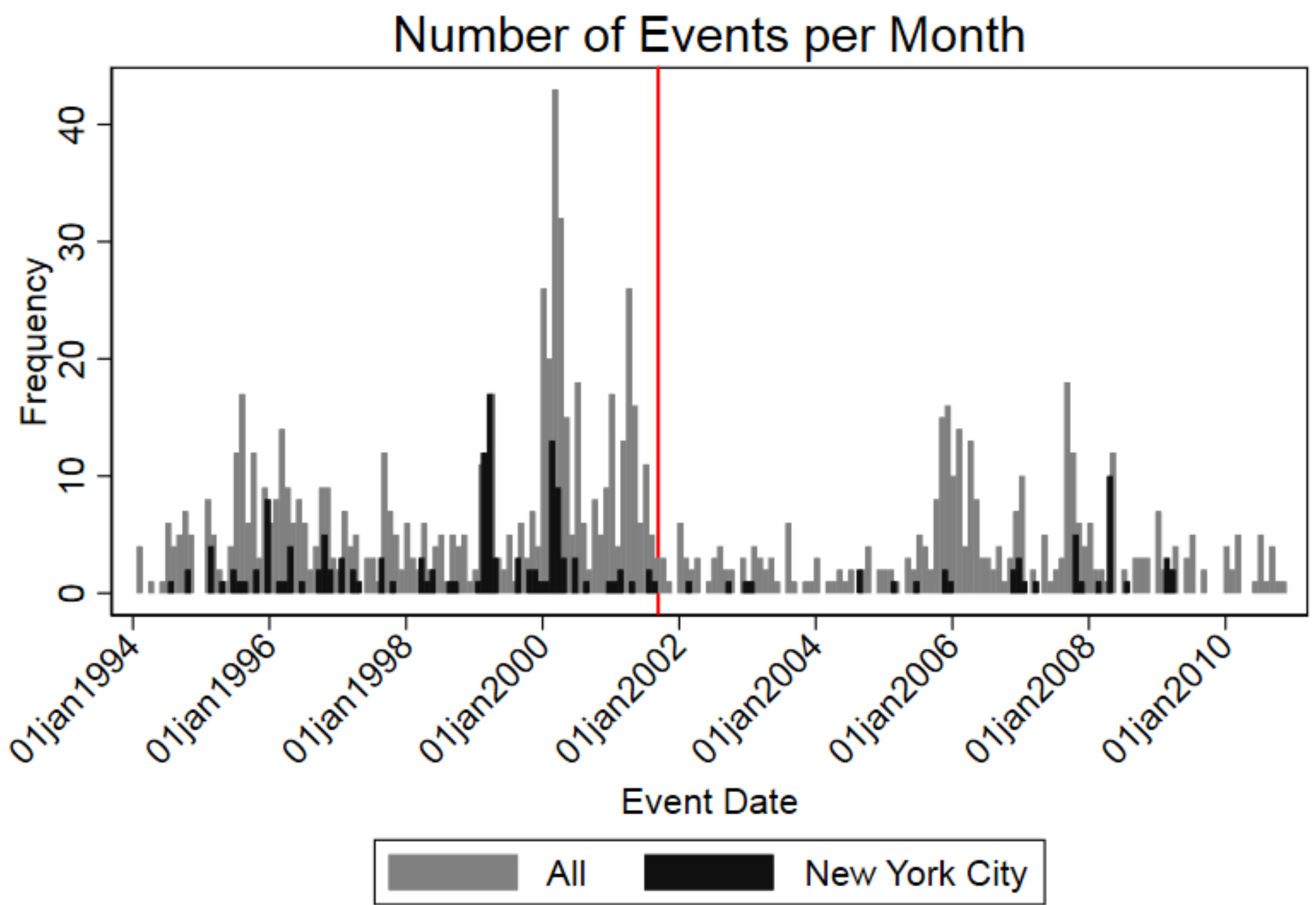

Red line is $9 / 11 / 2001$ 
Figure 5 Timing of Articles About Black Protest

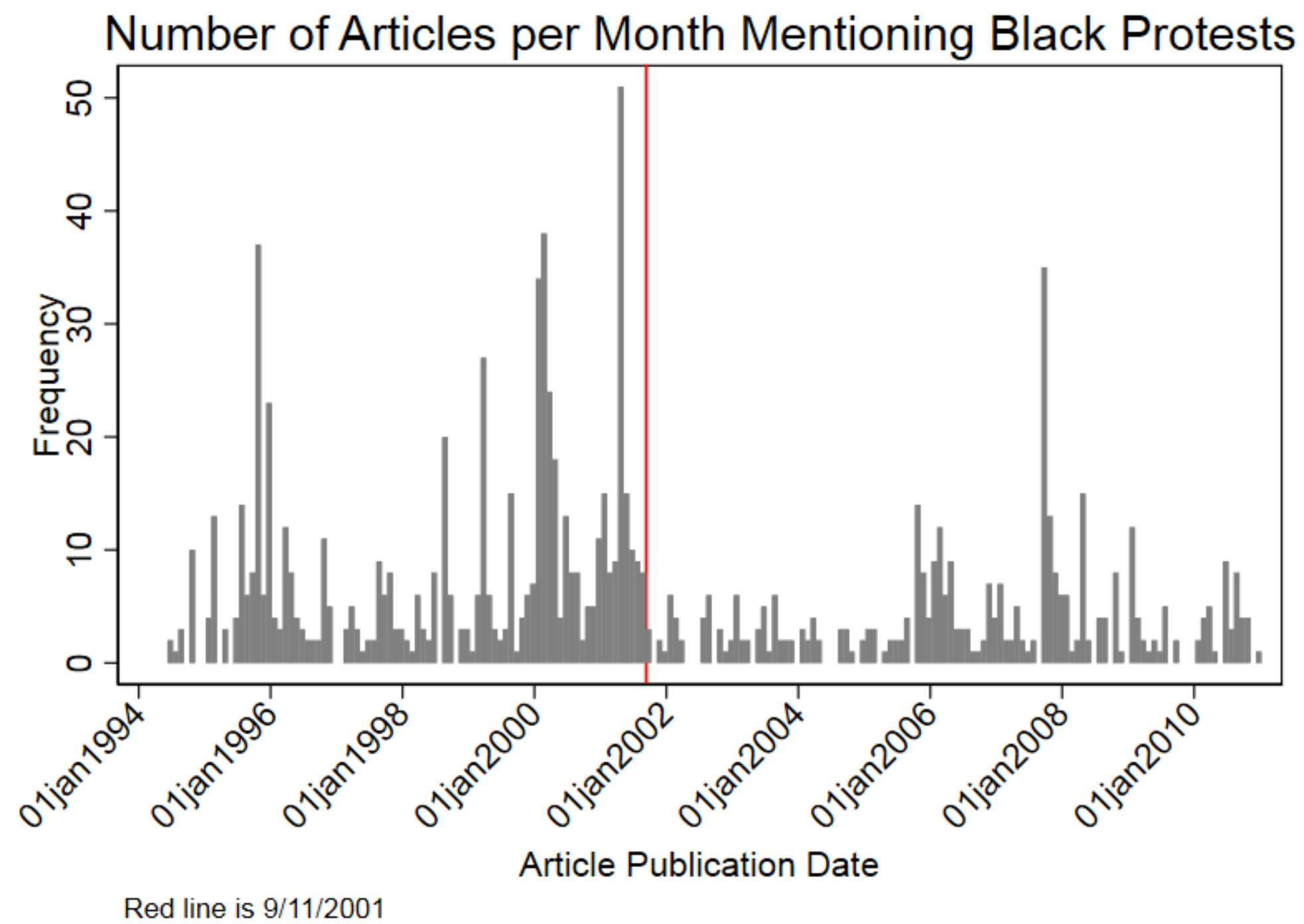


Figure 6. Issues in Events, Mentions of Events in Articles, and Articles

Issues for Events ( $n=1017)$

Issues in Articles $(n=1049)$

Issues for Event Mentions (n=1993)
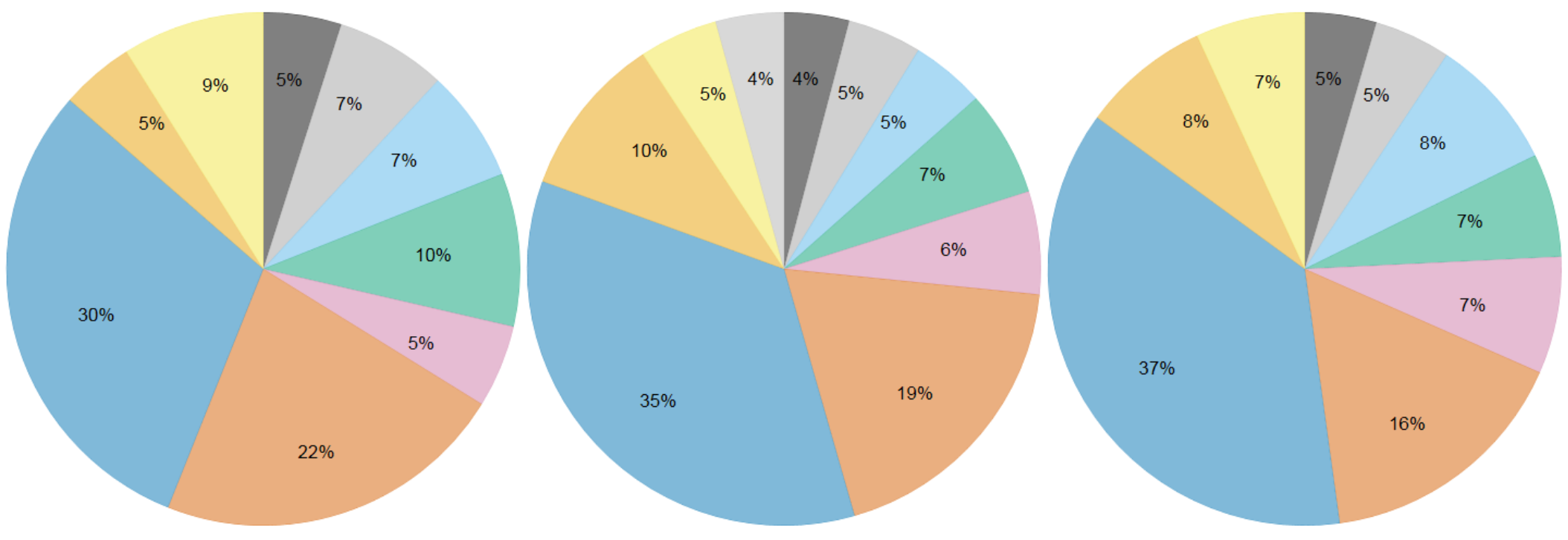

Affirmative_Action $\square$ Black_History $\square$ Confederate $\square$ Economic $\square$ Group_Conflict
Other


Figure 7 Timing of Events for Different Issues
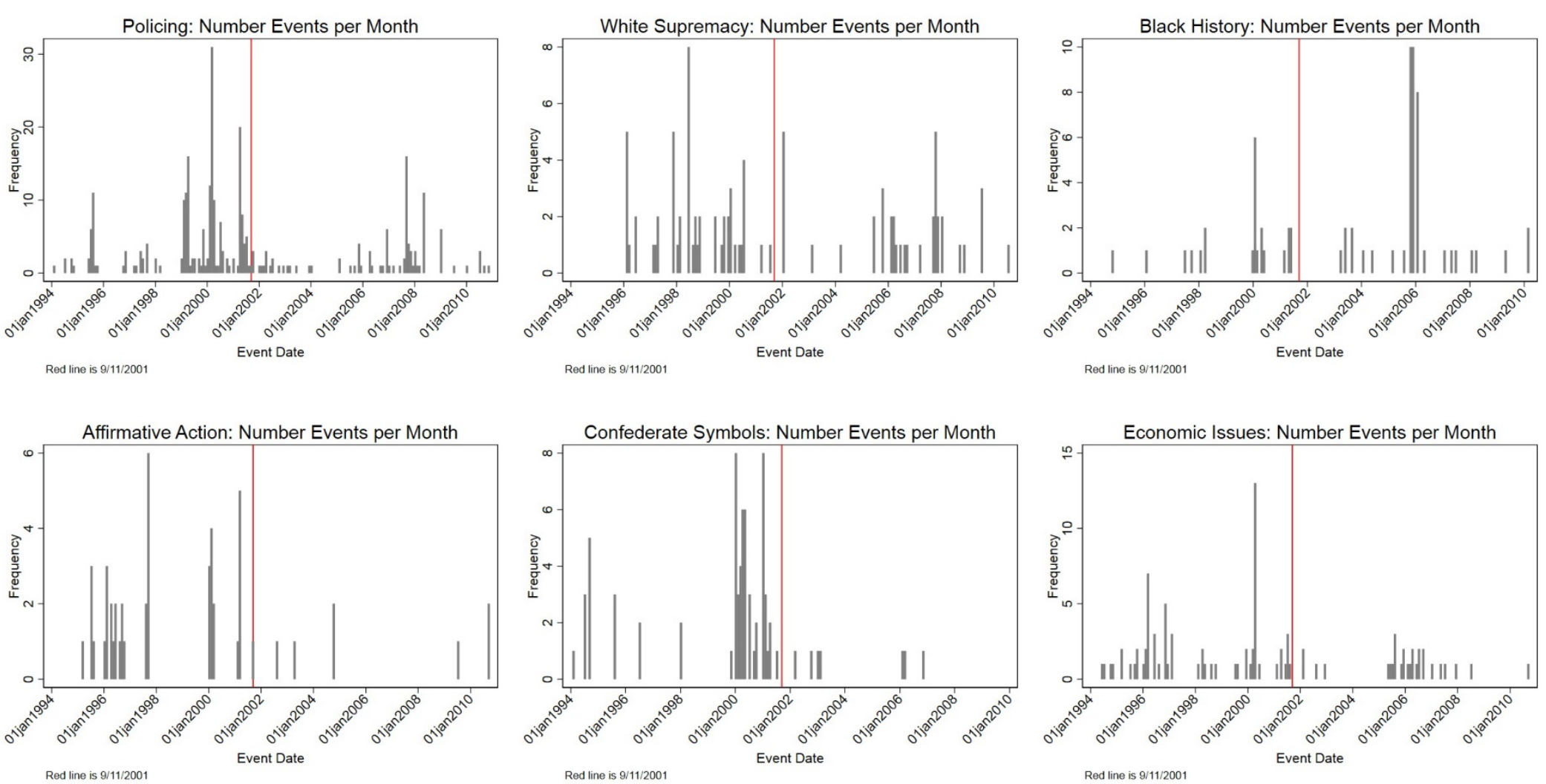
Figure 8 Timing of Articles Covering Protests About Different Issues
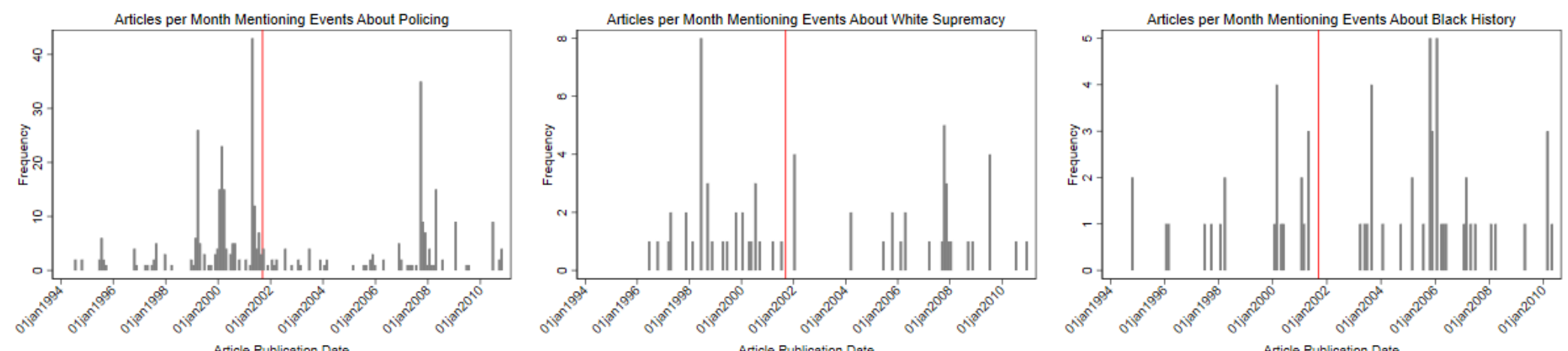

Fed IIn 15 9:11/2001

Fed Ine 15 9/11/2001

Fed Ine 18 9/11/200
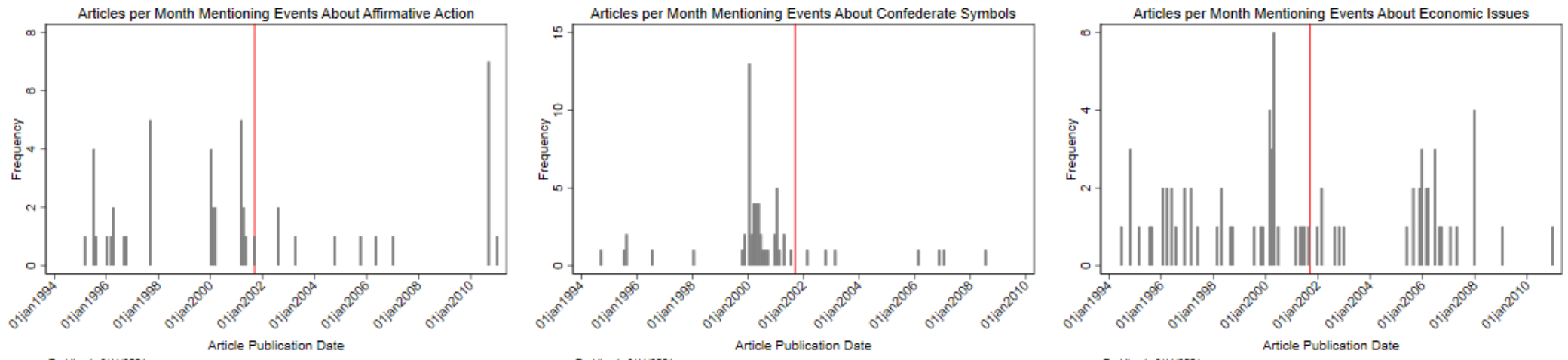

Red line 15 9:1112001

Fed llne is 9:1112001

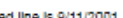




\section{REFERENCES}

Amenta, Edwin, Neal Caren, Sheera Joy Olasky and James E. Stobaugh. 2009. "All the Movements Fit to Print: Who, What, When, Where, and Why SMO Families Appeared in the New York Times in the Twentieth Century." American Sociological Review 74(4):636-56.

Andrews, Kenneth T. and Neal Caren. 2010. "Making the News: Movement Organizations, Media Attention, and the Public Agenda." American Sociological Review 75(6):841-66. doi: $10.1177 / 0003122410386689$.

Asoka, Kaavya. 2015. "Women and Black Lives Matter." Pp. 54-61, Vol. 62: University of Pennsylvania Press.

Baxandall, Rosalyn. 2001. "Re-Visioning the Women's Liberation Movement's Narrative: Early Second Wave African American Feminists." Feminist Studies 27(1):225.

Bell, Joyce. 2004. "'Do's and Don'ts:" the Black Press, Racial Etiquette, and Black Politics of Resistance, 1956-1969." Pp. 1: American Sociological Association.

Bell, Reston N., Tiffany J. Jones, Ricshawn Adkins Roane, Kidist M. Square and Rita Chi-Ying Chung. 2013. "Reflections on the Murder of Trayvon Martin." Journal for Social Action in Counseling \& Psychology 5(1):88-102.

Berg, Herbert. 2005. "Mythmaking in the African American Muslim Context: The Moorish Science Temple, the Nation of Islam, and the American Society of Muslims." Journal of the American Academy of Religion 73(3):685-703. doi: 10.1093/jaarel/Ifi075.

Berger, Dan. 2009. "Rescuing Civil Rights from Black Power. (Cover Story)." Journal for the Study of Radicalism 3(1):1-27.

Bergin, Cathy. 2016. "'Unrest among the Negroes': The African Blood Brotherhood and the Politics of Resistance." Race \& Class 57(3):45-58. doi: 10.1177/0306396815609844.

Biggs, Michael. 2016. "Size Matters." Sociological Methods \& Research:0049124116629166. doi: $10.1177 / 0049124116629166$.

Bonilla, Yarimar and Jonathan Rosa. 2015. "\#Ferguson: Digital Protest, Hashtag Ethnography, and the Racial Politics of Social Media in the United States." American Ethnologist 42(1):4-17. doi: doi:10.1111/amet.12112.

Boyd, Michelle. 2008. "Defensive Development: The Role of Racial Conflict in Gentrification." Urban Affairs Review 43(6):751-76.

Brame, Wendy and Thomas Shriver. 2013. "Surveillance and Social Control: The Fbi's Handling of the Black Panther Party in North Carolina." Crime, Law \& Social Change 59(5):501-16. doi: 10.1007/s10611-013-9426-1.

Brand, Anna Livia. 2008. "Rebuilding Resilience through Urban Social Movements in Post-Katrina New Orleans." Conference Papers -- American Sociological Association:1.

Breitzer, Susan Roth. 2011. "Race, Immigration, and Contested Americanness: Black Nativism and the American Labor Movement, 1880--1930." Race/Ethnicity: Multidisciplinary Global Perspectives 4(2):269-83. doi: 10.2979/racethmulglocon.4.2.269.

Brewer, Rose M. 2003. "Black Radical Theory and Practice: Gender, Race, and Class." Socialism and Democracy 17(1):109-22. doi: 10.1080/08854300308428344.

Brooms, Derrick R. and Armon R. Perry. 2016. "“It's Simply Because We're Black Men". "Journal of Men's Studies 24(2):166-84. doi: 10.1177/1060826516641105.

Brown, Nicole Marie. 2015. "Freedom's Stock: Political Consumerism, Transnational Blackness and the Black Star Line." Critical Sociology (Sage Publications, Ltd.) 41(2):237-48. doi: 10.1177/0896920514529675. 
Croicu, Mihai and Nils B. Weidmann. 2015. "Improving the Selection of News Reports for Event Coding Using Ensemble Classification." Research \& Politics 2(4):2053168015615596.

De Choudhury, Munmun, Shagun Jhaver, Benjamin Sugar and Ingmar Weber. 2016. "Social Media Participation in an Activist Movement for Racial Equality." in Proceedings of the Tenth International AAAI Conference on Web and Social Media (ICWSM 2016).

Fletcher, Bill, Jr. and Jamala Rogers. 2014. "No One Said That It Would Be Easy." Black Scholar 44(1):86112. doi: 10.5816/blackscholar.44.1.0086.

Freelon, Deen, Charlton Mcllwain and Meredith Clark. 2016. "Quantifying the Power and Consequences of Social Media Protest." new media \& society:1461444816676646.

Gill, Emmett L. 2016. "“Hands up, Don't Shoot” or Shut up and Play Ball? Fan-Generated Media Views of the Ferguson Five." Journal of Human Behavior in the Social Environment 26(3/4):400-12. doi: 10.1080/10911359.2016.1139990.

Hanna, Alex. 2016. "Media Ecology and Backlash Mobilization: Black Political Repression and \#Blacklivesmatter." Pp. 94-127 in Automated Coding of Protest Event Data: Development and Applications. University of Wisconsin - Madison. : Unpublished PhD dissertation.

Hanna, Alex. 2017. "Mpeds: Automating the Generation of Protest Event Data." Deposited at SocArXiv https://osf.io/preprints/socarxiv/xuqmv.

Harris, Angelique C. 2014. "Aids Activism among African American Women: Identity and Social Justice." Research in Social Movements, Conflicts \& Change 37:181-204. doi: 10.1108/S0163$786 \times 20140000037006$.

Hines, Revathi I. 2015. "The Price of Pollution: The Struggle for Environmental Justice in Mossville, Louisiana." Western Journal of Black Studies 39(3):198-208.

Jenkins, J. Craig, David Jacobs and Jon Agnone. 2003. "Political Opportunities and African-American Protest, 1948--1997." American Journal of Sociology 109(2):277-303.

King, Gary and Will Lowe. 2003. "An Automated Information Extraction Tool for International Conflict Data with Performance as Good as Human Coders: A Rare Events Evaluation Design." International Organization 57(3):617-42. doi: 10.1017/S0020818303573064.

Luna, Zakiya. 2009. "From Rights to Justice: Women of Color Changing the Face of Us Reproductive Rights Organizing." Societies Without Borders 4(3):343-65. doi: 10.1163/187188609X12492771031618.

Luna, Zakiya. 2016. "“Truly a Women of Color Organization”." Gender \& Society 30(5):769-90. doi: $10.1177 / 0891243216649929$.

Marakov, Peter, Jasmine Lorenzini, Klaus Rothenhäusler and Bruno Wüest. 2015. "Towards Automated Protest Event Analysis."

Martin, Andrew W., Patrick Rafail and John D. McCarthy. 2017. "What a Story?". Social Forces 96(2):779802. doi: $10.1093 /$ sf/sox057.

McAdam, Doug, Robert J. Sampson, Simon Weffer and Heather Maclndoe. 2005. "'There Will Be Fighting in the Streets": The Distorting Lens of Social Movement Theory." Mobilization: An International Journal 10(1):1-18.

Nardulli, Peter F., Scott L. Althaus and Matthew Hayes. 2015. "A Progressive Supervised-Learning Approach to Generating Rich Civil Strife Data." Sociological Methodology:0081175015581378.

Neville, Helen A. and Jennifer F. Hamer. 2006. "Revolutionary Black Women's Activism: Experience and Transformation." Black Scholar 36(1):2-11.

O'Brien, Sean P. 2010. "Crisis Early Warning and Decision Support: Contemporary Approaches and Thoughts on Future Research." International Studies Review 12(1):87-104.

Oliver, Pamela. 2017. "The Ethnic Dimensions in Social Movements." Mobilization: An International Quarterly 22(4):395-416. doi: 10.17813/1086-671x-22-4-395. 
Rafail, Patrick. 2018. "Protest in the City: Urban Spatial Restructuring and Dissent in New York, 19602006." Urban Studies (Sage Publications, Ltd.) 55(1):244-60.

Ralph, Michael. 2009. ""It's Hard out Here for a Pimp ... with ... a Whole Lot of Bitches Jumpin' Ship": Navigating Black Politics in the Wake of Katrina." Public Culture 21(2):343-76. doi: 10.1215/08992363-2008-032.

Richie, Beth. 2012. Arrested Justice Black Women, Violence, and America's Prison Nation: New York : New York University Press, c2012.

Robinson, Randall. 2000. The Debt : What America Owes to Blacks. New York: Dutton.

Rogers, Jamala. 2015. Ferguson Is America: Roots of Rebellion: Jamala Rogers.

Schrodt, Philip A, Erin M Simpson and Deborah J Gerner. 2001. "Monitoring Conflict Using Automated Coding of Newswire Reports: A Comparison of Five Geographical Regions." Pp. 8-9 in Conference 'Identifying Wars: Systematic Conflict Research and it's Utility in Conflict Resolution and Prevention', Uppsala.

Schrodt, Philip A. and Deborah J. Gerner. 1994. "Validity Assessment of a Machine-Coded Event Data Set for the Middle East, 1982-92." American Journal of Political Science:825-54.

Seguin, Charles. 2016. "Cascades of Coverage: Dynamics of Media Attention to Social Movement Organizations." Social Forces 94(3):997-1020. doi: 10.1093/sf/sov085.

Soule, Sarah, Doug McAdam, D. McCarthy John and Susan Olzak. n.d. "Dynamics of Collective Action." http://web.stanford.edu/group/collectiveaction/cgi-bin/drupal/.

Taylor, Keeanga-Yamahtta. 2016. From \#Blacklivesmatter to Black Liberation. Chicago, Illinois: Haymarket Books.

Taylor, Verta. 1989. "Social Movement Continuity: The Women's Movement in Abeyance." American Sociological Review 54(5):761-75.

van de Rijt, Arnout, Eran Shor, Charles Ward and Steven Skiena. 2013. "Only 15 Minutes? The Social Stratification of Fame in Printed Media." American Sociological Review 78(2):266-89. doi: 10.1177/0003122413480362.

Walgrave, Stefaan and Rens Vliegenthart. 2010. "Why Are Policy Agendas Punctuated? Friction and Cascading in Parliament and Mass Media in Belgium." Journal of European Public Policy 17(8):1147-70. doi: 10.1080/13501763.2010.513562.

White, Janelle L. 2005. "Our Silence Will Not Protect Us: Black Women's Experiences Mobilizing to Confront Sexual and Domestic Violence." Pp. 1-36: American Sociological Association.

Williams, Johnny E. 2004. "Vanguards of Hope: The Role of Culture in Mobilizing African-American Women's Social Activism in Arkansas." Sociological Spectrum 24(2):129-56. doi: 10.1080/02732170490271753.

Wueest, Bruno, Klaus Rothenhäusler and Swen Hutter. 2013. "Using Computational Linguistics to Enhance Protest Event Analysis."

Zamora, Sylvia and Chinyere Osuji. 2014. "Mobilizing African Americans for Immigrant Rights: Framing Strategies in Two Multi-Racial Coalitions." Latino Studies 12(3):424-48. doi: 10.1057/Ist.2014.47. 


\section{NOTES}

${ }^{1}$ This research was funded by National Science Foundation grant \#1423784. Much earlier versions of this paper with what turned to be incomplete data including only articles mentioning boycotts were presented at the Mobilization Conference in San Diego, California in May 2017 and the American Sociological Association conference in Montreal, Quebec in August 2017.

${ }^{2}$ It should be noted that an issue code as African American civil rights is not the same as events peopled by African Americans. To the extent that the Black people organized events around other issues such as police brutality or neighborhood development or anti-drug mobilization or religion, the plot in Figure 1 may be an undercount of all Black protest activity. Adjusting for this is unlikely to change the basic pattern in the data, however.

3 ((Black OR African American OR African-American) AND (protest OR movement) )

${ }^{4}$ The New York Times and Associated Press Worldstream files cover the entire period 19942010. The Los Angeles Times - Washington Post files are for 1994-8 and 2003-9. There are also stories for 2010 from the Washington Post Bloomberg service.

${ }^{5}$ It may be possible to do some methodological assessment of this issue, but for present purposes we take the news wire stories as given. We are aware that in some cases, several virtuallyidentical stories are filed on the same day as one or two later-breaking sentences are added to a previous story. In these cases, it is reasonable to assume that only one of these stories per day was ever printed in local newspapers. We plan to adjust for this as we refine the analysis.

${ }^{6}$ We found no Connecticut Black protest events for 1994 and 1995

${ }^{7}$ First author's personal memories.

${ }^{8}$ The first author attended pro-reparations presentations by local activists in 2000 or 2001 which were part of this movement. These activists attended the Durban World Conference Against Racism which was held August 31 to September 8 in 2001. The first author also recalls debating the idea of reparations with relatives during this time. 